[Review]

\title{
碱性固体燃料电池碱性聚合物电解质膜的最新研究进展
}

\author{
侯宏英* \\ (昆明理工大学材料科学与工程学院, 昆明 650093)
}

\begin{abstract}
摘要: 最近, 碱性聚合物电解质膜燃料电池(APEMFC)因具有电极反应动力学快以及不依赖于贵金属铂催化 剂等诸多优点而成为一个热门话题. 作为其中一个关键部件, 碱性聚合物电解质膜直接影响燃料电池的性能和 成本. 然而, 迄今为止, 仍然没有令人满意的碱性电解质膜材料. 为此, 大量研究被开展和报道. 本文综述了近三 年内文献中关于燃料电池碱性聚合物电解质膜的最新研究进展: 包括各种各样的合成策略, 构效关系, 水管理 以及非原位或原位稳定性测试等等. 尤其是一些新的金属离子基阴离子交换膜和冠醚基阴离子交换膜首次被 提及和评论. 此外, 还进一步预测了将来的发展趋势.
\end{abstract}

关键词：碱性固体燃料电池；碱性聚合物电解质膜；阴离子交换膜；复合膜； 非铂催化剂 中图分类号: 0646

\section{Recent Research Progress in Alkaline Polymer Electrolyte Membranes for Alkaline Solid Fuel Cells}

\author{
HOU Hong-Ying* \\ (Faculty of Materials Science and Engineering, Kunming University of Science and Technology, Kunming 650093, P. R. China)
}

\begin{abstract}
Alkaline polymer electrolyte membrane fuel cell (APEMFC) has received much recent attention, primarily motivated by their fast dynamics and independence on expensive Pt-based electrocatalysts. As one of vital components of APEMFC, the alkaline polymer membrane directly influences their performance and cost. However, to date, no alkaline membrane has provided a satisfactory benchmark for use in APEMFC. Therefore, intensive efforts have been made to pursue desirable polymer membrane materials. In this article, the research progress over the last 3 years on state-of-the-art alkaline polymer electrolyte membranes for APEMFC is reviewed, including various synthesis strategies, structure-property relationships, water management, and ex situ and in situ stability tests. More specifically, some new metal-cation-based anion exchange membranes, such as ruthenium-complex-based and crown-ether-based anion exchange membranes, are commented on for the first time. Furthermore, future development prospects are also predicted.
\end{abstract}

Key Words: Alkaline solid fuel cell; Alkaline polymer electrolyte membrane; Anion exchange membrane; Composite membrane; Non-Pt catalyst

\section{Introduction}

The rapid development of fuel cells was triggered by the global fossil energy crisis, and many breakthroughs have been made. However, there still exist some challenges prior to wide com-

Received: April 21, 2014; Revised: June 16, 2014; Published on Web: June 17, 2014.

"Corresponding author. Email: hhy@dicp.ac.cn; hongyinghou@kmust.edu.cn; Tel: +86-871-65107922.

The project was supported by the National Natural Science Foundation of China (51363011), the 46th Scientific Research Foundation for the Returned Overseas Chinese Scholars, Ministry of Education, China (6488-20130039), Program of High-level Introduced Talent of Yunnan Province in 2012, China (10978125), and Yunnan Project of Training Talent, China (1418425) and Project of Key Discipline, China (14078232).

国家自然科学基金(51363011), 第46批教育部留学归国基金(6488-20130039), 云南省 2012 年高层次引进人才经费(10978125), 云南省人才培 养基金(1418425)和重点学科项目(14078232)资助项目 
mercialization. For example, successful application of proton exchange membrane such as Nafion ${ }^{\circledR}$ (Dupont) significantly promoted the development of proton exchange membrane fuel cell (PEMFC). However, the coming commercialization of PEMFC was also postponed by some challenges such as high fuel permeability and high cost of Nafion ${ }^{\circledR}$ membrane, the heavy dependence on the expensive scarce Pt-based catalysts, and high susceptibility to CO-like species poison effect. ${ }^{1-4}$ In the case of conventional alkaline fuel cell (AFC), it has a successful and glorious history to land on the moon together with Apollo spacecraft in 1960s due to fast dynamics and low dependence on Pt-based catalyst, but alkali leakage and carbonation usually disable its long term operation. Therefore, the combination of the advantages of PEMFC and AFC naturally aroused the emergence of alkaline polymer electrolyte membrane fuel cell (APEMFC). For example, APEMFC can possess the compact structure, avoid the leakage of liquid alkaline electrolyte, and inhibit the susceptibility to CO-like species poison effect. Meanwhile, it can also get rid of the heavy dependence on expensive scarce Pt-based catalyst, because more inexpensive non-Pt catalysts exhibited similar activity in alkaline electrode reactions. ${ }^{5,6}$ It was reported that electrochemical reactions in both electrodes were more facile in the alkaline medium than in the acid medium. ${ }^{7-9}$ Therefore, some cheap available non-platinum catalysts such as $\mathrm{Pd},{ }^{10-12} \mathrm{Ru},{ }^{13}$ $\mathrm{Au},{ }^{14,15} \mathrm{Ag},{ }^{16,17} \mathrm{Co},{ }^{18,19} \mathrm{Cu}^{20} \mathrm{Ni}^{21} \mathrm{MnO}_{2},{ }^{22}$ even metal-free carbon nanotubes and graphene nanosheets ${ }^{23-26}$ can exhibit satisfying catalytic activity in the alkaline electrochemical reactions. And also, the loading of catalyst can be as low as possible. ${ }^{27}$ Additionally, the charge carrier in APEMFC is not the proton but the anion, which moves from the cathode to the anode, opposite to the moving direction of the proton in PEMFC. Fuel crossover due to electro-osmosis drag can be avoided accordingly, which can be confirmed by experiment results and theory calculation. ${ }^{28,29}$ Low sensibility to CO-like species poisoning effect of the catalysts in alkaline medium also expanded the range of the fuels suitable for APEMFC, not only including $\mathrm{H}_{2}$ and low carbon alcohols (methanol, ethanol, and glycerol), but also other liquid fuels such as sodium borohydride, hydrazine, formate, and ammonia. ${ }^{30-35}$ Therefore, the investigation about APEMFC has been a hot topic. As one of the key components, alkaline polymer electrolyte membrane played a vital role in maintaining the normal operation of APEMFC, and thus the availability of desirable alkaline polymer electrolyte membrane for APEMFC was very crucial and important. In principle, ideal alkaline polymer electrolyte membrane for APEMFC should possess high ionic conductivity, excellent thermal and mechanical stability, chemical inertness, easy availability as well as low cost. Unfortunately, there has not been available benchmark alkaline polymer electrolyte membrane for APEMFC yet, because no actual alkaline membrane material can meet all the requirements as mentioned above. Especially, high alkali-resistance of alkaline membrane is still a challenge, that is, functional quaternized group responsible for the ionic conductivity is easily subjected to the decomposition and degradation in alkaline medium. For this purpose, the intensive efforts to develop the alkaline polymer electrolyte membrane have been made. ${ }^{36-39}$ Especially within recent three years, newer and better results were reported, such as metal-cation-based anion exchange membrane, ${ }^{40}$ water management, ${ }^{41}$ in situ durability, ${ }^{42-44}$ electrode binder for triple-phase structure, ${ }^{45}$ theory analysis ${ }^{46}$ and so on. Herein, in this review, the state-of-the-art alkaline polymer electrolyte membranes for APEMFC mainly in recent three years were covered, and the next development prospects were also predicted. Alkaline polymer electrolyte membranes for APEMFC can be classified into three kinds: (i) quaternized anion exchange membrane; (ii) metal-cation-based anion exchange membrane; (iii) inorganic/ organic hybrid alkaline membrane. These membranes will be introduced one by one in terms of synthesis strategy, accompanied with the structure-property relationship as well as the applications in APEMFC.

\section{Anion exchange membrane}

As a counterpart of cation exchange membrane, typical anion exchange membrane (AEM) usually contains cation-anion pairs: fixed positive group and movable anion, thus allowing for the passage of the anion but rejecting the cation. ${ }^{47-49}$ In fact, it was developed prior to alkaline fuel cell and applied in many other fields such as salt electrodialysis, ${ }^{50}$ anion selective electrode, ${ }^{51}$ water treatment ${ }^{52}$ recovery of waste organic acids ${ }^{53}$ and battery. ${ }^{54}$ Only in recent years, increasing efforts have been made to study the application for APEMFC. Usually, a desirable membrane for APEMFC should possess a stable hydrophobic matrix for the structural mechanical integrity and some continuous hydrophilic channels for anion transport. ${ }^{55}$ Among all the properties, enough ionic conductivity is the most vital to normal operation of fuel cell, because too poor ionic conductivity can result in too high inner resistance and disable the fuel cell. Generally speaking, there are three major strategies to improve the ionic conductivity of anion exchange membrane: (i) increasing the density of cationanion pairs, that is, ion-exchange capacity (IEC) of the polyelectrolyte; (ii) increasing the effective mobility of the charge carrier $\left(\mathrm{OH}^{-}\right)$; (iii) improving the alkali-resistance of functional groups for ionic conductivity.

The next is the summary of intensive efforts to pursue desirable anion exchange membranes with potential application for APEMFC.

\subsection{Quaternized anion exchange membrane}

Generally, quaternized anion exchange membrane (QAEM) is composed of three parts: (i) the polymer matrix; (ii) the fixed quaternized group with positive charge; (iii) the movable anion. $-\mathrm{NR}_{4}^{+},-\mathrm{PR}_{4}^{+}$, and $-\mathrm{SR}_{4}^{+}$are three kinds of common positive quaternized groups. QAEM with $\mathrm{NR}_{4}^{+}$groups was the most common anion exchange ionomer, although it was reported that $-\mathrm{PR}_{4}^{+}$-based anion exchange membrane had higher thermal and chemical stability than $-\mathrm{NR}_{4}^{+}$and $-\mathrm{SR}_{4}^{+} \cdot{ }^{56}$ Commercial QAEMs are available from several companies such as Tokuyama ${ }^{\circledR}$ in Japan, ${ }^{57-62}$ Selemion ${ }^{\circledR}$ AMV in Japan, ${ }^{63}$ Morgane ${ }^{\circledR}$-ADP Solvay S. A. in Belgium, ${ }^{64,65}$ Dupont ${ }^{\circledR}$ in American, ${ }^{66}$ and Fumatech ${ }^{\circledR}$ in 
Germany, ${ }^{67}$ although many of these materials are not optimized for alkaline fuel cell applications.

Most of the commercial QAEMs are based on crosslinked polystyrene or their blends with other inert polymers. For example, Tokuyama ${ }^{\circledR}$ anion exchange membrane consists of polystyrene backbone and side chains with terminated $-\mathrm{NR}_{4}^{+}$groups, and it is the most popular commercial QAEM. Like in Nafion ${ }^{\circledR}$ membrane, the Schroeder's paradox phenomenon was also found in Tokuyama ${ }^{\circledR}$ anion exchange membrane, and the water diffusivity of Tokuyama ${ }^{\circledR}$ anion exchange membrane showed same order of magnitude $\left(10^{-10} \mathrm{~m}^{2} \cdot \mathrm{s}^{-1}\right)$ as that of Nafion ${ }^{\circledR}$ membrane. ${ }^{68}$ In early literature, the peak power density of alkaline direct alcohol fuel cell with Tokuyama ${ }^{\circledR}$ membrane was low. ${ }^{69,70}$ Recently, new breakthrough in peak power density of $130 \mathrm{~mW} \cdot \mathrm{cm}^{-2}$ at $80{ }^{\circ} \mathrm{C}$ was achieved with $5 \mathrm{~mol} \cdot \mathrm{L}^{-1} \mathrm{KOH}$ and $3 \mathrm{~mol} \cdot \mathrm{L}^{-1}$ ethanol into the anode. ${ }^{71}$ More surprisingly, in situ stability without significant decline of Pt-free alkaline ethanol fuel cell with this kind of membrane at $60{ }^{\circ} \mathrm{C}$ can sustain for $520 \mathrm{~h}$, as shown in Fig. $1 .^{72}$

Quantitative product analysis of ethanol oxidation in alkaline direct ethanol fuel cell with Tokuyama ${ }^{\circledR}$ anion exchange membrane was also performed. It was found that incomplete ethanol oxidation to acetate prevailed over complete oxidation to $\mathrm{CO}_{2}{ }^{73}$ But increasing the operation temperature from 60 to $100^{\circ} \mathrm{C}$ can improve the current efficiency of $\mathrm{CO}_{2}$ from $6.0 \%$ to $30.6 \%$. Additionally, considering that the susceptibility of alkaline medium to acid $\mathrm{CO}_{2}$, Suzuki et al. ${ }^{74}$ evaluated the influence of $\mathrm{CO}_{2}$ on APEMFC performances. It was confirmed that the anode was more vulnerable than the cathode when $\mathrm{CO}_{2}$ was supplied to the anode and cathode, respectively, and high $\mathrm{CO}_{2}$ concentration significantly reduced the single cell performance. This result indicated that it was important to remove the carbonate ion species in the triple-phase boundary in order to alleviate the electrode over-potential. Studies on water management showed that cathode flooding also occurred because the water diffusion flux from the anode to the cathode was surplus during the operation of APEMFC. ${ }^{75}$

Morgane $^{\circledR}$-ADP membrane is a cross-linked fluorinated poly-

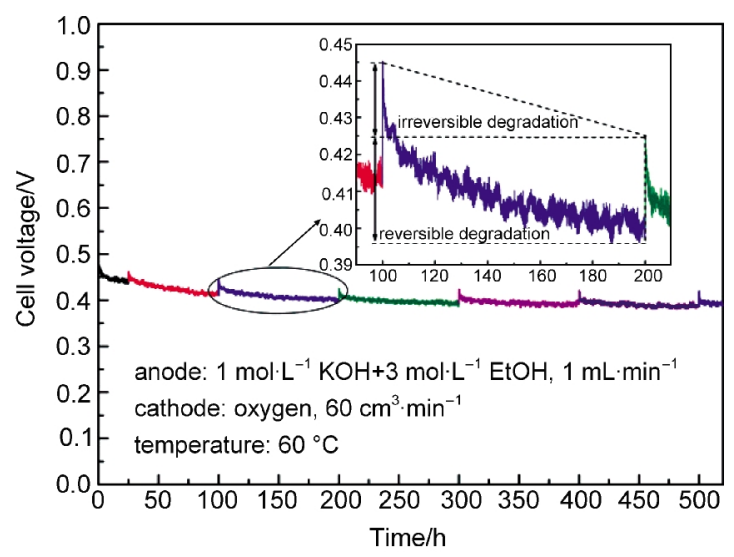

Fig.1 In situ stability test for $520 \mathrm{~h}$ of alkaline direct ethanol fuel cell with Tokuyama ${ }^{\circledR} \mathrm{A} 201$ membrane at a constant current density of $50 \mathrm{~mA} \cdot \mathrm{cm}^{-2}$ at $60{ }^{\circ} \mathrm{C}^{72}$ mer with quaternary ammonium group, and it exhibits a higher resistance but a lower methanol diffusion coefficient compared to Nafion ${ }^{\circledast}$ membrane. At $60{ }^{\circ} \mathrm{C}$, the peak power density of alkaline direct methanol fuel cell with this membrane was about $16 \mathrm{~mW}$. $\mathrm{cm}^{-2}$, when the solution containing $2 \mathrm{~mol} \cdot \mathrm{L}^{-1}$ methanol and $2 \mathrm{~mol} \cdot$ $\mathrm{L}^{-1} \mathrm{NaOH}$ was fed into the anode. ${ }^{65}$

In order to pursue more desirable single cell performance of APEMFC, more quaternized anion exchange membranes were designed, optimized, and synthesized in the laboratory. ${ }^{76-84}$ Typically, QAEMs were synthesized via chloromethylation of the pristine polymers and subsequent exposure to trimethylamine (TMA) to form benzyltrimethyl-type quaternary ammonium (QA) head-groups. ${ }^{85}$ In principle, quaternized anion exchange membranes can be synthesized by simple one-step nucleophilic substitution reaction of an aminated polymer (or monomer) with a halogenated monomer (or polymer), and then the resultant materials could be readily quaternized to form a potentially inexpensive QAEM if necessary. ${ }^{86,87}$ Therefore, for functional starting materials with $\mathrm{N}$-containing, Cl-containing, or Br-containing groups, the synthesis of QAEM seems very facile and simple. In the case of nonfunctional starting materials, the functionalizations such as cholormethylation, halogenation, or ammonification are indispensible. Considering the toxicity of chloromethyl methyl ether during the cholormethylation, quaternized anion exchange membrane can be synthesized by two methods: one is prepared with chloromethylether, and the other is prepared without chloromethylether.

\subsubsection{Quaternized anion exchange membrane with chloromethylether}

Generally, the preparation route with chloromethylether includes three steps: (i) the non-functionlized starting polymer is chloromethylaed; (ii) the resultant polymer is quaternized with trimthylamine, and thus quaternary ammonium groups are introduced into the polymer matrix; (iii) the membrane is dipped into $\mathrm{KOH}$ or $\mathrm{NaOH}$ solution for $\mathrm{OH}^{-}$form. Obviously, this synthesis strategy belongs to post-functionalization, in which some available thermoplastic engineering plastics (such as poly(ether ether ketone), poly(ether sulfone), polyimide and so on) or copolymers from monomers can be the starting polymer materials. ${ }^{88-96}$ During the chloromethylation of the polymer, the most common and classical chloromethylating agents are chloromethyl methyl ether (CMME) and bis-chloromethyl ether (BCME), which can allow for high conversions and yields. For example, a quaternary ammonium polymer was synthesized by chloromethylation of commercial polysulfone, followed by amination process, as shown in Fig. $2 .{ }^{97}$ The ionic conductivity of the as-synthesized anion exchange membrane was $0.032 \mathrm{~S} \cdot \mathrm{cm}^{-1}$ in deionized water at $24{ }^{\circ} \mathrm{C}$, and the alkali-resistance of the polymer in $8.0 \mathrm{~mol} \cdot \mathrm{L}^{-1}$ $\mathrm{KOH}$ solution was also satisfying.

Novel anion conductive multi-block copolymers with sequential hydrophobic/hydrophilic structure were synthesized via polycondensation, chloromethylation, quaternization, and final alkalization. ${ }^{98-100}$ Compared with the first method in Fig.2, such a method can offer more choices to design and optimize the 


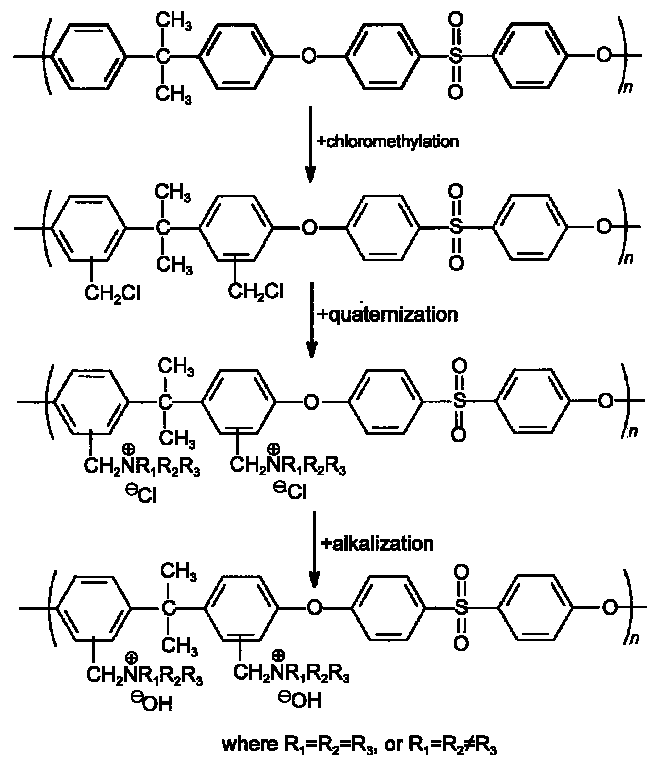

Fig.2 Preparation route of quaternized commercial polysulfone with chloromethylether ${ }^{97}$

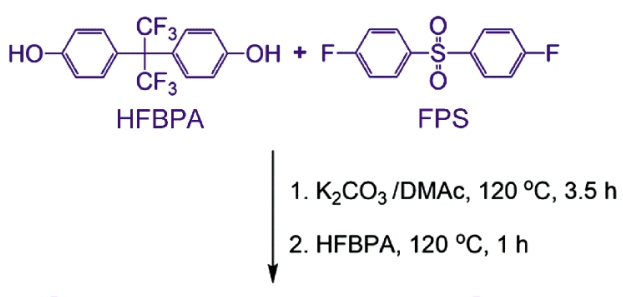

structure-property relationship for desirable anion exchange membrane, such as excellent nano-phase separation morphology. Fig.3 showed the synthesis route of anion-conductive multiblock copoly(arylene ether sulfone)s with different chain lengths, hydrophilia and hydrophobicity. ${ }^{101}$ The newest satisfying result was that $\mathrm{H}_{2}$-fueled APEMFC with crosslinked quaternized polysulfone membrane via this method can output the peak power density of $342 \mathrm{~mW} \cdot \mathrm{cm}^{-2}$ at $70{ }^{\circ} \mathrm{C}$. ${ }^{102}$

\subsubsection{Quaternized anion exchange membrane without chloromethylether}

Although the route with chloromethylether as mentioned above is efficient and typical, unfortunately, chloromethyl methyl ether and bis-chloromethyl ether used in most cases are well known to be carcinogenic, and thus have been restricted since 1970s. Therefore, more friendly approaches towards their avoidance have been developed. Firstly, some safer alternative chloromethylating agents have been investigated. It was reported that high reactive long chain chloro methyl octyl ether (CMOE) ${ }^{103-106}$ inexpensive 1,4-bis (chloromethoxy) butane, ${ }^{107,108}$ paraformaldehyde and chlo-

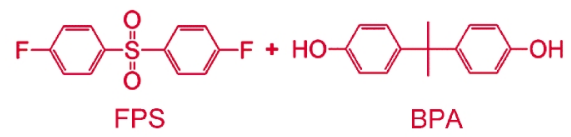

FPS

BPA

1. $\mathrm{K}_{2} \mathrm{CO}_{3} / \mathrm{DMAC}, 110^{\circ} \mathrm{C}, 7 \mathrm{~h}$
2. $\mathrm{FPS}, 110^{\circ} \mathrm{C}, 1 \mathrm{~h}$

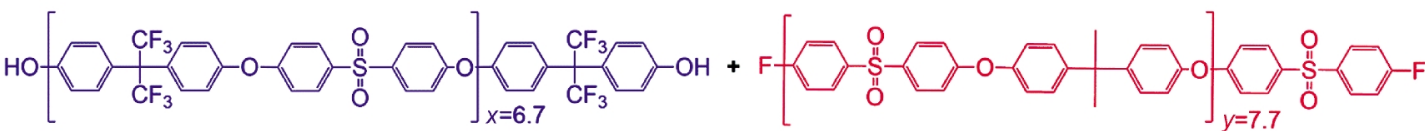

$\mathrm{K}_{2} \mathrm{CO}_{3} / \mathrm{DMAc}, 130^{\circ} \mathrm{C}, 2 \mathrm{~h}$

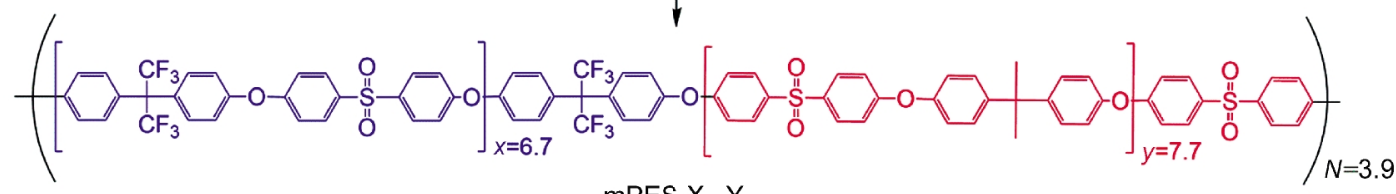

mPES- $X_{6.7} Y_{7.7}$

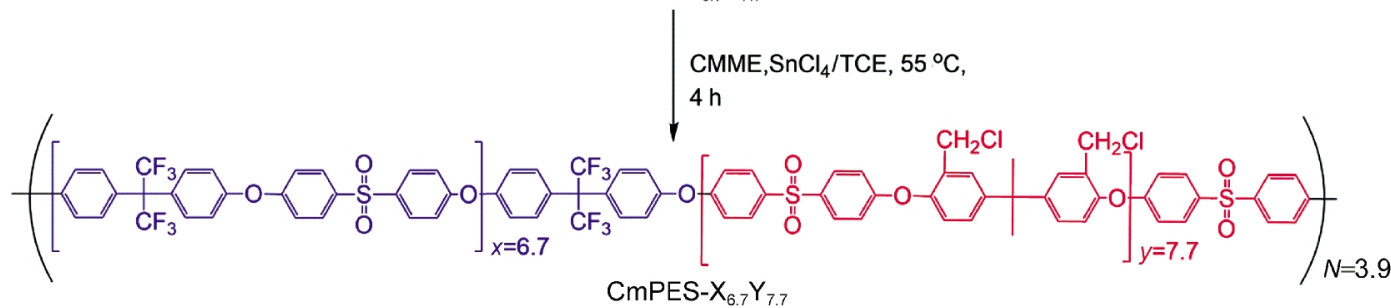

1. $\mathrm{N}(\mathrm{Me})_{3}$ (aq.)

2. $\mathrm{KOH}$ (aq.)

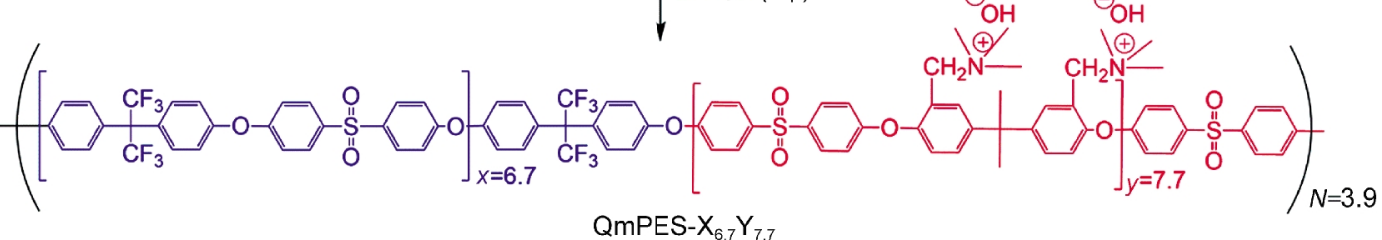

Fig.3 Synthetic route of quaternized multiblock poly(arylene ether sulfone) with chloromethylether ${ }^{101}$

DMAc: $N, N$-dimethylacetamide; HFBPA: 4,4'-(hexafluoroisopropylidene) diphenol; CMME: chloromethyl methyl ether; TCE: 1,1,2,2-tetrachloro ethane 
rotrimethylsilane ${ }^{109-111}$ were applied to perform the chloromethylation. For example, Han et al. ${ }^{112}$ recently achieved chloromethylation of poly(ether ether ketone) (PEEK) by using sulfonated PEEK and chlorotrimethylsilane as the starting polymer and chloromethylating agents, respectively, in which $-\mathrm{SO}_{3} \mathrm{H}$ groups of sulfonated PEEK can be partially substituted by quaternary group. The ionic crosslinking between remaining $-\mathrm{SO}_{3} \mathrm{H}$ groups and quaternized groups occurred and resulted in an outstanding alkali-resistance to $1 \mathrm{~mol} \cdot \mathrm{L}^{-1} \mathrm{KOH}$ solution at $80^{\circ} \mathrm{C}$ for 30 days.

Beside the strategy of using alternative chloromethylating agents, chloromethylation can also be achieved by directly radiation-grafting vinylbenzyl chloride (VBC) onto the polymer matrix $^{113}$ or by bottom-up poly-condensation of functional VBC and other monomers. ${ }^{114}$ The resultant membrane can be quaternized with tertiary ammonium and ion-exchanged with $\mathrm{KOH}$. In the case of the radiation-grafting method, some available fluorine-containing polymer films such as poly(vinylidenefluoride) $(\mathrm{PVDF})^{115}$, poly(ethylene-co-tetrafluoro-ethylene) (ETFE), ${ }^{116,117}$ poly (tetrafluoro-ethene-co-hexafluoro-propylene) (FEP), ${ }^{118}$ and poly (tetrafluoroethylene-co-perfluoropropyl vinyl ether) (PFA) ${ }^{119,120}$ membranes were pre-irradiated via plasma bombardment, electron-beam, or $\gamma$-ray source in order to induce the formation of the radicals. Then vinylbenzyl chloride was grafted onto these preactivated polymer films, followed by quaternization with amine and alkalization. For example, ETFE-based membrane exhibited the ionic conductivity of $20-40 \mathrm{mS} \cdot \mathrm{cm}^{-1}$ at room temperature, moreover, the ionic conductivity did not significantly degrade during the storage for 16 months. ${ }^{121}$ When this kind of membrane was used as anion exchange membrane for $\mathrm{H}_{2} / \mathrm{O}_{2}$ alkaline fuel cell, the output peak power density was as high as $230 \mathrm{~mW} \cdot \mathrm{cm}^{-2} \cdot{ }^{122}$ Recently, superior peak power densities of $823 \mathrm{~mW} \cdot \mathrm{cm}^{-2}$ at $60{ }^{\circ} \mathrm{C}$, $718 \mathrm{~mW} \cdot \mathrm{cm}^{-2}$ at $50{ }^{\circ} \mathrm{C}$, and $648 \mathrm{~mW} \cdot \mathrm{cm}^{-2}$ at $20^{\circ} \mathrm{C}$ for APEMFC were also achieved as shown in Fig. $4 .{ }^{123}$

Compared to acid Nafion ${ }^{\circledR}$ membrane, these anion exchange membranes exhibited lower fuel permeability, solvent uptakes, and swelling degrees in methanol, ethanol, and ethylene glycol, thus allowing for the use of thinner membrane with lower ionic

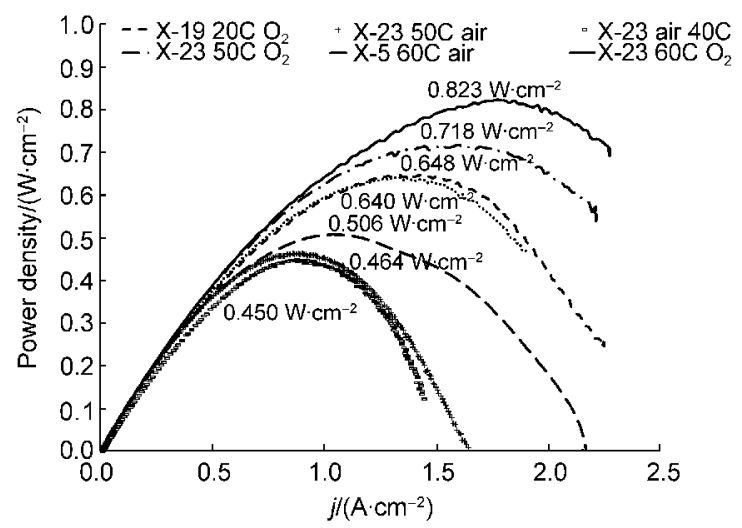

Fig.4 Peak power densities of APEMFCs with the radiationgrafting membranes $(5,19$, and $23 \mu \mathrm{m})$ in the temperature range from 20 to $60^{\circ} \mathrm{C}$ under air and oxygen ${ }^{123}$ resistance and offsetting the intrinsically lower $\mathrm{OH}^{-}$conductivity accordingly. In addition, Ko et al. ${ }^{124}$ compared the effects of the base films on the properties of QAEM. It was found that partially fluorinated films such as ETFE and PVDF exhibited better radiation-resistance than fully fluorinated films, because the radiation-inducing radicals were produced mainly via $\mathrm{C}-\mathrm{H}$ fission in the partially fluorinated films, while it was formed by undesirable $\mathrm{C}-\mathrm{C}$ fission in the fully fluorinated films. For example, it was reported that polytetrafluoroethylene (PTFE) exclusively underwent main chain fission because $\mathrm{C}-\mathrm{C}$ bonds are weaker than $\mathrm{C}-\mathrm{F}$ bonds and break prior to $\mathrm{C}-\mathrm{F}$ bonds. ${ }^{125}$ Additionally, high cost is a concern of this kind of materials too. It seems that fluorinated polymers may be less suitable polymer substrates for radiation-induced grafting. Therefore, other alternative substrate polymers were recently used for radiation-grafting QAEM. ${ }^{126-129}$ For example, polyethylene-based radiation-grafting QAEM was synthesized, and the obtained QAEM exhibited a maximum ionic conductivity of $47.5 \mathrm{mS} \cdot \mathrm{cm}^{-1}$ at $90{ }^{\circ} \mathrm{C}$, while the order of methanol permeability was as low as $10^{-8} \mathrm{~cm}^{2} \cdot \mathrm{s}^{-1}$, significantly lower than that of Nafion ${ }^{\circledR}$ membrane, implying potential feasibility for APEMFC.

Apart from radiation-grafting technology, VBC can be also introduced into the polymer matrix by direct bottom-up polymerization. VBC is an excellent monomer for synthesis of QAEMs via polymerization because of its double functional groups: vinyl group for polymerization and benzyl chloride group for quaternization. ${ }^{130-134}$ Based on this conception, Xu et al. ${ }^{135}$ synthesized the copolymer from the monomers of VBC, methyl methacrylate (MMA) and ethyl acrylate (EA) by free radical polymerization, as shown in Fig.5. By this method, some desirable properties of the as-synthesized QAEM, such as ionic conductivity, ion exchange capacity, mechanical properties, and water uptake, can be easily achieved by tuning the stoichiometric ratio of different monomers. Sometimes, macromolecular crosslinker or PTFE can be used to further improve the mechanical and thermal stability of PVBC. ${ }^{136}$ In addition, considering that a large excess of the solvent used in polymerization and membrane formation may bring about the toxic risk to the environment, it is desirable to develop simple friendly methods for production of quaternized anion exchange membrane. Herein, Wu et al. ${ }^{137,138}$ developed a friendly solvent-free synthesis strategy. In detail, the polymerization started in liquid monomers instead of additional solvents, followed by in situ polymerization and then quaternization for preparation of QAEM.

The fourth preparing route without chloromethylether can be actualized via some available nitrogen-containing, halogen-containing, or oxygen-containing starting materials such as 4-vinylpyridine, halide, chitosan, poly(vinyl alcohol) and so on. ${ }^{139}$ In the case of nitrogen-containing starting materials, the quaternization can be easily achieved by direct SN2 nucleophilic substitution reaction with halohydrocarbon. ${ }^{140,141}$ For example, Wan et al. ${ }^{142}$ synthesized a series of quaternized chitosan derivatives (QCDs) with glycidyltrimethylammonium chloride as a main quaternized agent. After tuning the degree of crosslinking and quaternization, the as-synthesized quaternary chitosan membranes showed con- 


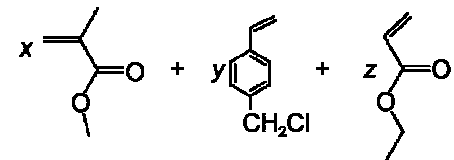

step 1: copolymerization $]\left[\begin{array}{l}\text { AlBN } \\ 65^{\circ} \mathrm{C}, 8 \mathrm{~h}\end{array}\right.$

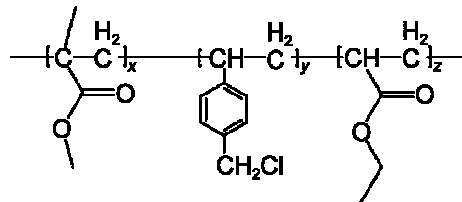

step 2: quaternization $] \mathrm{N}\left(\mathrm{CH}_{3}\right)_{3}$

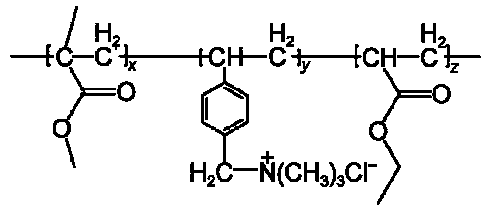

step 3: alkalization $] 1 \mathrm{~mol} \cdot \mathrm{L}^{-1} \mathrm{KOH}$

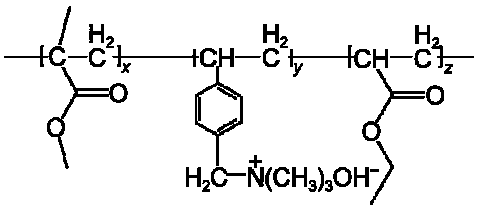

Fig.5 Direct bottom-up copolymerization of VBC and other monomers for quaternized anion exchange membrane ${ }^{135}$ AIBN: azobisisobutronitrile

trollable crystallinity, swelling behavior, ionic conductivity, and thermal stability, indicating potential applications for APEMFC. Likewise, the bottom-up copolymerization of N-containing monomer and other monomers provided an alternative synthesis route. ${ }^{143,144}$ The resonance effect of the guanidine moiety or imidazole ring can reduce the charge density of the cation, weaken the hydroxide attack to the cation, and improve the alkali-resistance of QAEM. ${ }^{145-148}$ For example, Zhang et al. ${ }^{149}$ designed and prepared a pore-filling membrane via polymerization of 3methacryloylamino propyl trimethylammonium chloride in a porous substrate. The water movement of APEMFC with this membrane was accurately observed by a water collection method. It was experimentally confirmed for the first time that the water moved from the anode to the cathode, opposite to the moving direction of the proton in acid polymer electrolyte membrane fuel cell. The model calculation also showed that the $\mathrm{Ohm}$ resistance of the membrane can reduce as much as possible when the relative humidity was high enough by desirable water movement. ${ }^{149}$

Ionic liquids, a new class of benign organic electrolytes, have remarkable physicochemical properties, such as ideal conductivity, wide electrochemical window, low volatility, and excellent thermal and chemical stability. Imidazolium-type ionic liquids have been used as the monomers for QAEM preparation due to their high ionic conductivity, stability and solubility. ${ }^{150-153}$ As<smiles></smiles>

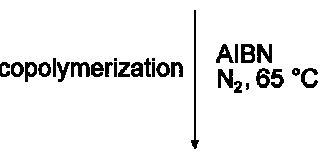

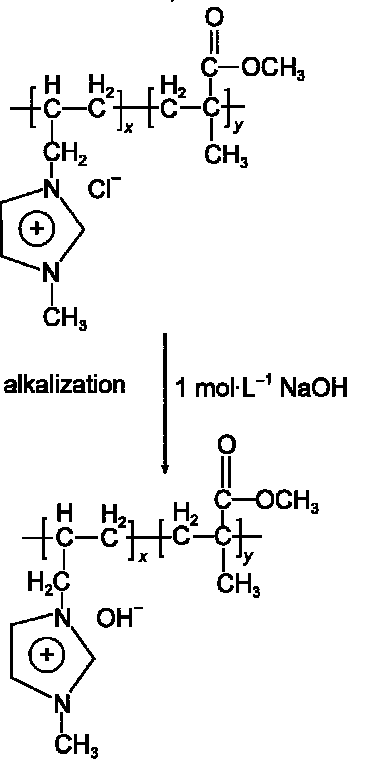

Fig.6 Synthesis of poly(amimCl-MMA) membrane in $\mathrm{OH}$ form: co-polymerization and alkalization ${ }^{154}$

shown in Fig.6, novel anion exchange membranes were prepared by copolymerization of imidazolium-type ionic liquids and alkyl acrylates. ${ }^{154}$ The hydroxyl ionic conductivity of the as-synthesized membrane can reach as high as $3.33 \times 10^{-2} \mathrm{~S} \cdot \mathrm{cm}^{-1}$ in deionized water at $30^{\circ} \mathrm{C}$. The ex situ stability tests showed that the onset of mass loss was above $200{ }^{\circ} \mathrm{C}$, and the membranes still maintained good ionic conductivity in $6 \mathrm{~mol} \cdot \mathrm{L}^{-1} \mathrm{NaOH}$ solution at $80^{\circ} \mathrm{C}$ for $120 \mathrm{~h}$. Such membranes exhibited superior thermal stability and alkali resistance than alkyl quaternary ammonium polymers.

Halogen-containing starting polymer can be directly quaternized in an aqueous trimethylamine solution for some time, and then final quaternary ammonium anion exchange membrane was obtained via ion-exchanging with $\mathrm{KOH}$ solution. ${ }^{155}$ Additionally, nonfunctional polymer plastics such as poly(ether ether ketone) (PEEK), polyether sulfone (PES), and polyphene oxide (PPO) or other copolymers from the monomers can also be used as the starting materials, but it is necessary to perform the halogenations in advance, that is, bromination or chlorination in most cases. ${ }^{156-164}$ By this method, comb-shaped PPO-based QAEM was designed and prepared, and the resultant membrane can maintain the initial ionic conductivity in $1 \mathrm{~mol} \cdot \mathrm{L}^{-1} \mathrm{NaOH}$ solution for as long as 2000 $\mathrm{h}$ at $80^{\circ} \mathrm{C} .{ }^{165} \mathrm{~A}$ novel PES-based QAEM was also successfully prepared, in which bromination reaction was carried out for preparing the target membranes. The corresponding ionic conductivity at 30 and $80{ }^{\circ} \mathrm{C}$ in deionized water was $6.00 \times 10^{-2}$ and $13.00 \times 10^{-2} \mathrm{~S} \cdot \mathrm{cm}^{-1}$, respectively, while its methanol permeability 
was as low as $1.02 \times 10^{-9} \mathrm{~cm}^{2} \cdot \mathrm{s}^{-1}$ at $30{ }^{\circ} \mathrm{C} \cdot{ }^{166}$ Considering that the flexibility of pendant side chain can promote better micro-phase separation, higher conductivity, and dimensional stability of the conductive polymer, Shen et al. ${ }^{167}$ designed and prepared poly(aryl ether ketone) with methyl groups on pendant phenyls, in which $\mathrm{N}$ bromosuccinimide (NBS) was used for the bromination of the methyl groups on pendant phenyls. The ionic conductivity of the final polymer was $0.024 \mathrm{~S} \cdot \mathrm{cm}^{-1}$ at $20^{\circ} \mathrm{C}$ and $0.0307 \mathrm{~S} \cdot \mathrm{cm}^{-1}$ at $80{ }^{\circ} \mathrm{C}$ in deionized water, respectively. Likewise, Lin et al..$^{168,169}$ synthesized PPO-based novel anion exchange membranes containing pendant guanidinium or benzimidazolium groups. The resultant QAEMs exhibited high ionic conductivity, excellent thermal stability and alkali-resistance attributed to the $p$ electron conjugated system of the pendant guanidinium or benzimidazolium head-groups.

In the case of oxygen-containing starting materials, poly(vinyl alcohol) (PVA) is a kind of common starting material due to its outstanding features: low cost, good film-forming ability, chemical stability, and availability of crosslinking sites. In this case, QAEM can be synthesized by open-ring polycondensation of PVA and bifunctional compounds with epoxy and quaternized groups, in which epoxy group was responsible for combination with PVA main chain, while quaternized group was responsible for the ionic conductivity. As displayed in Fig.7, Ye et al. ${ }^{170}$ quaternized PVA (QPVA) by directly grafting 4-methyl-4-glycidylmorpholinium chloride onto PVA. After crosslinked with glutaraldehyde, the resultant quaternized PVA membrane exhibited high ionic conductivity $\left(7.34 \times 10^{-3} \mathrm{~S} \cdot \mathrm{cm}^{-1}\right)$ and low methanol permeability. In addition, in order to further improve the transport property and durable performance of PVA-based QAME, quaternized $\mathrm{SiO}_{2}$ was added into the QPVA matrix. ${ }^{171,172}$

As mentioned above, intensive efforts were made to investigate quaternary anion exchange membranes for APEMFC application, and many significant progresses were made. For example, the highest power density of $\mathrm{H}_{2}$-fueled APEMFC with irradiationgrafting QAEM was as high as $823 \mathrm{~mW} \cdot \mathrm{cm}^{-2}$ at $60{ }^{\circ} \mathrm{C}$; and the in situ durability for $520 \mathrm{~h}$ of commercial Tokuyama ${ }^{\oplus}$ membrane was also achieved. However, up to now, there have not been wide and deep in situ stability tests for APEMFC yet, although a large quantity of new QAEMs was designed and synthesized. A widely quoted concern with quaternary anion exchange membranes is the stability in the alkaline environment, that is, alkali-resistance, especially at elevated temperatures. ${ }^{173}$ The recognized degradation

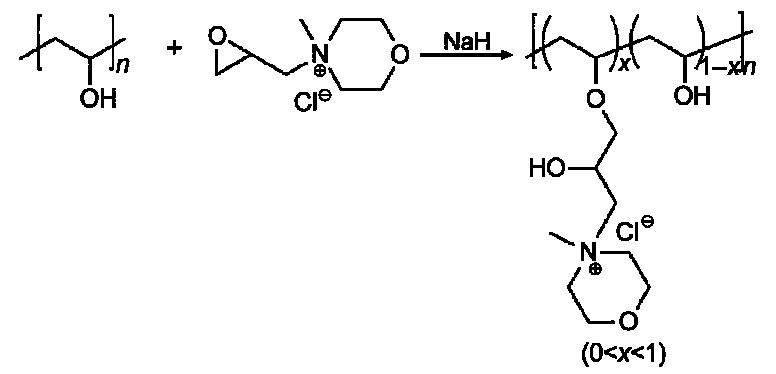

Fig.7 Synthetic reaction route for the preparation of QPVA mechanisms of quaternized groups include: (i) Hofmann elimination; (ii) nucleophilic substitution; (iii) Ylide formation. Hoffman elimination reaction usually results in the loss of quaternized group, wherein hydroxyl ion attacks $\beta$-hydrogen to the cation forming a double bond between $\alpha$-carbon and $\beta$-carbon. Density function theory (DFT) calculation also suggested that Hofmann elimination was the most vulnerable pathway to degradation. ${ }^{174}$ Direct nucleophilic displacement occurs via the attack to $\alpha$-carbon atom of the cation, which can either detach the cation groups from QAEM or convert quaternary ammonium groups into tertiary amines. Degradation through the Ylide pathway begins with hydroxyl ion's attack to a methyl group of the cations and produces a water molecule along with an Ylide intermediate.

In order to obtain QAEM with high stability, some strategies were applied: (i) some conjugated head-groups including guanidinium and imidazolium are introduced into QAEM in order to weaken the hydroxide attack to the cation and improve the alkaliresistance, as mentioned above; ${ }^{175}$ (ii) crosslinking among polymer chains for stronger mechanical property. ${ }^{176,177}$ In the case of the second strategy, some reinforced inorganic or organic fillers such as $\mathrm{TiO}_{2}{ }^{178} \mathrm{SiO}_{2}{ }^{179,180} \mathrm{ZrO}_{2},{ }^{181}$ crosslinked polyvinyl alcohol (PVA) ${ }^{182-184}$ or PTFE ${ }^{185-189}$ were also added into the matrix of QAEM for high mechanical stability. For example, Zhao et al. ${ }^{189}$ synthesized polyvinyl benzyl chloride membrane, which was crosslinked with diethylamine and reinforced by PTFE matrix. The obtained target membrane exhibited satisfying ex situ ionic conductivity stability and in situ durability for about $230 \mathrm{~h}$ with mild degradation, as shown in Fig.8.

Additionally, the possible reason resulting in low in situ durability may be also due to the absence of anion exchange ionomer binder for triple-phase boundary in the electrode, which is similar to Nafion ${ }^{\circledast}$ solution in proton exchange membrane fuel cell. As shown in Fig.9, alkaline polymer electrode binder can not only bond the catalyst particles together but also facilitate the ionic transport by building triple-phase boundary. ${ }^{190}$ Therefore, the development of alkaline polymer bond should be vital to assemble metal-cation-free alkaline membrane electrode assembly with long-term stability. ${ }^{191}$ However, for the moment, although there have existed different types of QAEMs in literature as discussed above, the corresponding suitable catalyst binder for APEMFC is not easily available yet. In early literature, ${ }^{192}$ PTFE or Nafion ${ }^{\circledR}$ ionomers were usually used as a temporary strategy to deal with this challenge. For example, Qiao et al. ${ }^{192}$ assembled metal-cationfree APEMFC still with Nafion ${ }^{\circledR}$ solution as electrode binder for constructing triple phase interface of electrochemical reaction, and the peak power density was only $32.7 \mathrm{~mW} \cdot \mathrm{cm}^{-2}$ at $25^{\circ} \mathrm{C}$. No doubt, this value would be better if suitable alkaline binder counterpart was used. As expected, the latest results showed that all-solid-state $\mathrm{H}_{2} / \mathrm{O}_{2}$ APEMFC can output the peak power density of $823 \mathrm{~mW} \cdot \mathrm{cm}^{-2}$ at $60{ }^{\circ} \mathrm{C}$ with poly(vinylbenzyl chloride) as electrode binder, which can rival with that of proton exchange membrane fuel cell. ${ }^{123}$ Additionally, layered double hydroxides, aminosilane-based and chloride conductive layer can also be in- 

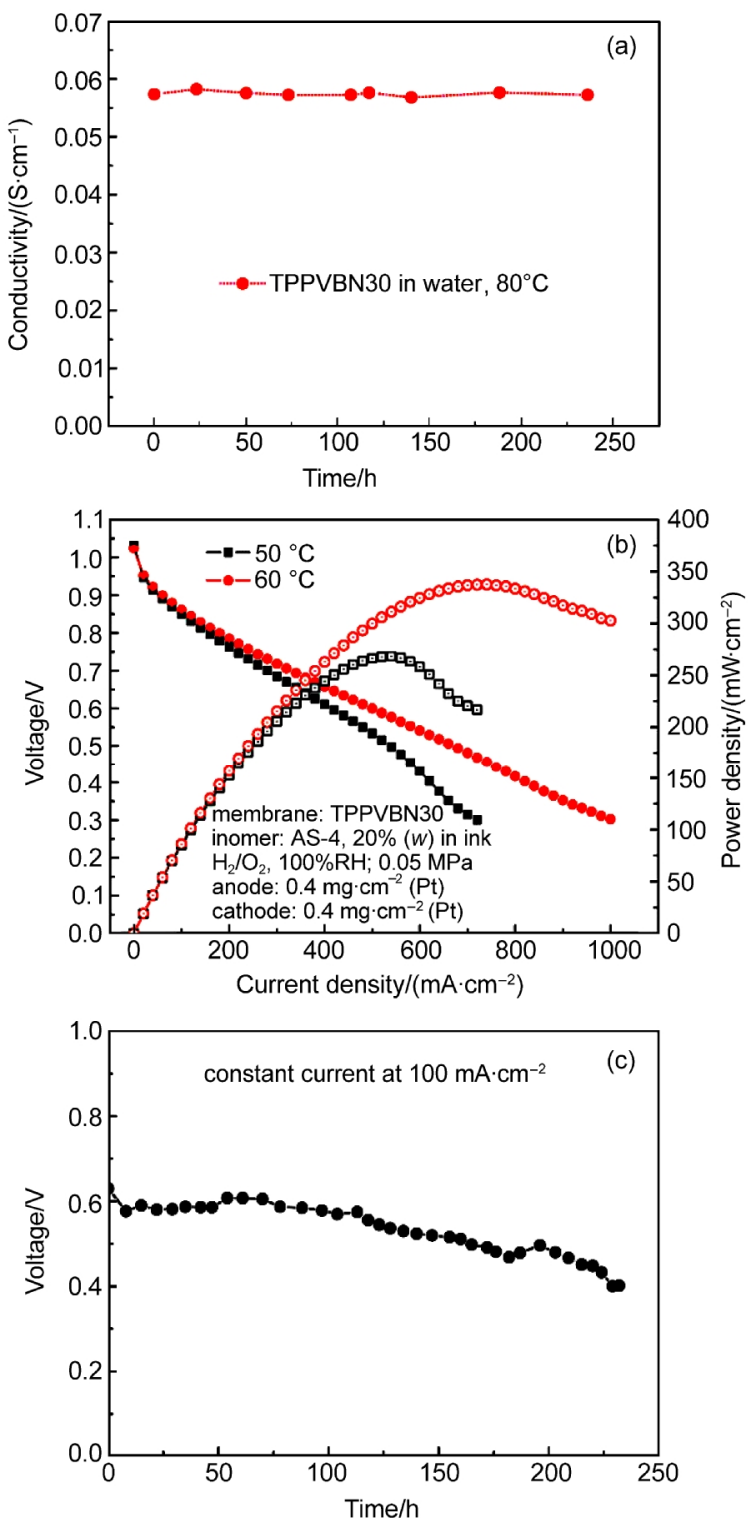

Fig.8 (a) Ionic conductivity stability test, (b) voltage-current density polarization curves, and (c) in situ stability test of alkaline $\mathrm{H}_{2} / \mathrm{O}_{2}$ fuel cell with crosslinked PTFE-reinforced polyvinyl benzyl chloride membrane ${ }^{189}$

TPPVBN30: quaternized polyvinyl benzyl chloride with $30 \%$ (molar fraction) of the benzyl chloride group; RH: relative humidity

corporated into the electrode structure to improve the triple-phase boundary. ${ }^{193-195}$

\subsection{Metal-cation-based anion exchange membrane}

Beside traditional quaternized anion exchange membrane, anion exchange membrane can also be synthesized via the chelation of metal cations with $\mathrm{N}$-containing or O-containing materials, in which metal cations such as $\mathrm{Ru}^{2+}$ and $\mathrm{K}^{+}$act as fixed positive groups, and anions acts as movable charge carriers. Based on this idea, novel metal-cation-based anion exchange membrane containing ruthenium complex was designed and synthesized recently. As shown in Fig. 10, ${ }^{40}$ each $\mathrm{Ru}^{2+}$ can combine with six nitrogen atoms containing lone electron pairs to form ruthenium

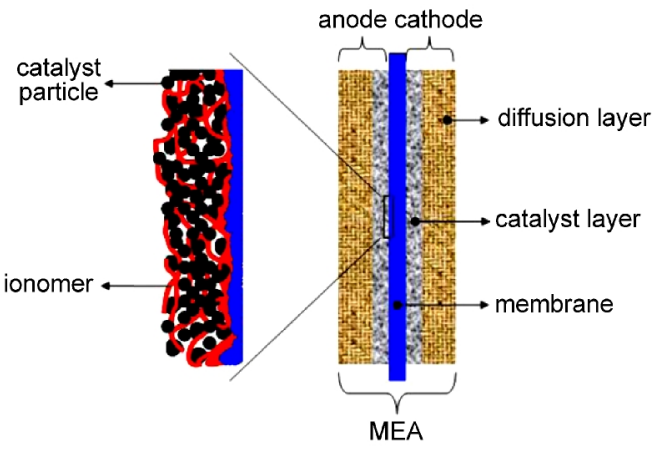

Fig.9 Schematic for the architecture of ionomer-bindercontaining membrane electrode assembly ${ }^{190}$

MEA: membrane \& electrode assembly

complex, and such a complex can have two associated counter anions, different from most ammonium-based and phosphoniumbased anion exchange membranes only with single cation-anion pairs. Such a new metal-cation-based anion exchange membrane exhibited higher anion conductivity, mechanical properties, alkaliresistance as well as methanol tolerance than traditional quaternary anion exchange membrane. ${ }^{40}$

Crown ethers are ring-shaped heterocyclic compounds containing several ether groups, and their repeating unit is ethyleneoxy group ( $\left.-\mathrm{CH}_{2} \mathrm{CH}_{2} \mathrm{O}-\right)$. Important members of this series are the tetramer $(n=4)$, the pentamer $(n=5)$, and the hexamer $(n=$ $6)$. Crown ethers can strongly combine with certain cations to form complexes. When metal atoms such as sodium or potassium pass through the center of the ring, they can attach themselves to the exposed oxygen atoms like a key in a lock. The denticity of the crown ether influences its affinity for various metal cations. For example, 18-crown-6 ether has high affinity for $\mathrm{K}^{+}, 15$-crown5 ether for $\mathrm{Na}^{+}$, and 12 -crown- 4 ether for $\mathrm{Li}^{+}$, respectively. ${ }^{196}$ The microstructure and ball-and-stick model of 18-crown- 6 ether coordinating a potassium ion are shown in Fig.11. Based on this property of crown ether, metal-cation-based anion exchange membrane can be synthesized by chemically grafting pendant 18 crown- 6 ether onto the polymer backbone, followed by combination of $\mathrm{KOH} \cdot{ }^{197}$ Similar to ruthenium complex, metal cation $\mathrm{K}^{+}$ can be fixed into the polymer matrix by chelating with 6 oxygen atoms, while $\mathrm{OH}^{-}$is unsolvated or naked and thus acts as the movable charge carrier. The obtained membrane displayed higher thermal stability, alkali-resistance, and ionic conductivity than quaternized anion exchange membrane, implying a potential application in APEMFC.

polybenzimidazole (PBI) membrane is well known to possess excellent endurance both in alkaline medium and at high temperature. ${ }^{198,199}$ It is a weak basic polymer due to two imidazole rings in one repeating unit of PBI matrix. Inherently, PBI is an electronic and ionic insulator, but it can become an ionic conductor by being functionalized with the acids ${ }^{200}$ and inorganic hydroxides ${ }^{201,202}$ apart from quaternization with halogenated hydrocarbons as mentioned above. Compared with acid-doped PBI membrane, there are fewer literature about alkali-doped PBI 


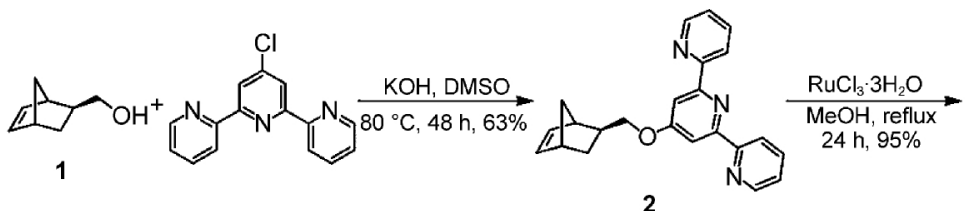

2

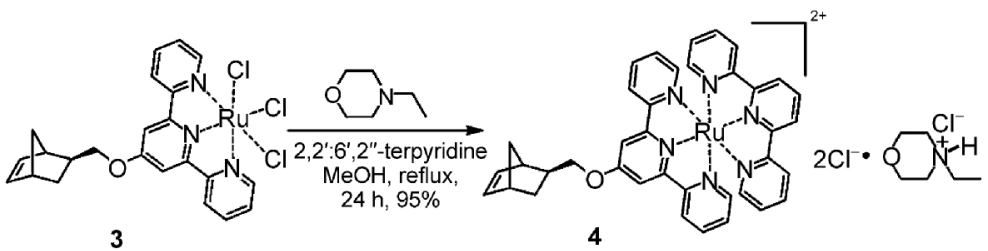

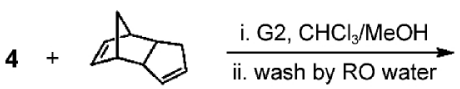

DCPD

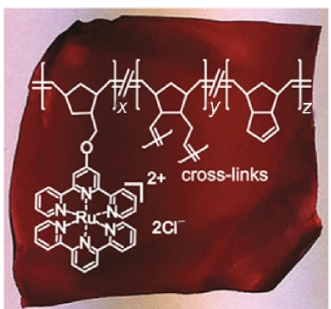

Fig.10 Synthesis of metal-cation-based anion exchange membrane ${ }^{40}$ DMSO: dimethyl sulfoxide; G2: the Grubbs' second generation catalyst; RO: reverse osmosis

membrane for alkaline fuel cell. The first investigation about alkali doped PBI membrane for alkaline $\mathrm{H}_{2} / \mathrm{O}_{2}$ fuel cell was reported in $2000 .^{203}$ Recently, the application of $\mathrm{PBI} / \mathrm{KOH}$ membrane for alkaline direct ethanol fuel cell was carried out and the satisfying results were achieved in our laboratory. ${ }^{204,205}$ The obtained membrane exhibited excellent thermal stability as well as in situ durability for $336 \mathrm{~h}$ in air-breathing Pt-free alkaline direct ethanol fuel cell at $60{ }^{\circ} \mathrm{C}$ (Fig. 12). ${ }^{206}$ When this kind of membrane was used in alkaline direct ethylene glycol fuel cell, the corresponding peak power density can reach as high as $80 \mathrm{~mW} \cdot \mathrm{cm}^{-2}$ at $60{ }^{\circ} \mathrm{C}$ and $112 \mathrm{~mW} \cdot \mathrm{cm}^{-2}$ at $90{ }^{\circ} \mathrm{C}$, respectively. The power output at $60{ }^{\circ} \mathrm{C}$ was $67 \%$ higher than that of acid direct ethylene glycol fuel cell, mainly attributed to the superior electrochemical kinetics of both ethylene glycol oxidation and oxygen reduction reactions in alkaline medium. ${ }^{207}$ The interaction between $\mathrm{KOH}$ and PBI matrix was also explored, and scanning electron microscope (SEM) and energy dispersive X-ray spectrometer (EDX) results showed that the concentration of $\mathrm{K}$ element within $\mathrm{PBI} / \mathrm{KOH}$ membrane was much higher than that of $\mathrm{O}$ element. Possible reason may be due to double resources of $\mathrm{K}$ element: (i) $\mathrm{K}^{+}$ combined with $-\mathrm{NH}-$ in $\mathrm{PBI}$ matrix, meanwhile, $\mathrm{H}_{2} \mathrm{O}$ was<smiles>C1COCCOCCOCCOCCO1</smiles>

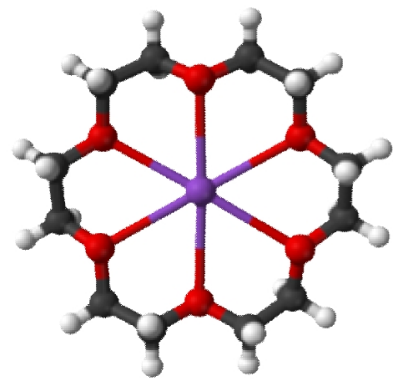

Fig.11 Microstructure and ball-and-stick model of 18-crown-6 ether coordinating a potassium ion produced and left as a result of a neutralization between $\mathrm{H}$ in $-\mathrm{NH}-$ and $\mathrm{OH}^{-}$in the medium (Fig.13), ${ }^{206}$ (ii) $\mathrm{K}^{+}$chelated with pyridine $-\mathrm{N}$ in $\mathrm{PBI}$ membrane by complexation with $\mathrm{OH}^{-}$ as movable charger carrier, thus endowing the membrane with the ionic conductivity.

\subsection{Organic/inorganic hybrid alkaline membrane}

Recently, organic/inorganic hybrid anion exchange membrane have gained much interest because suitable combination of two components can endow the composite with some remarkable changes in mechanical, thermal, and electrical properties compared to single material especially for those via molecular-level integration. Generally, organic polymers offer structural flexibility, convenient processing, and good film-forming ability, while inorganic phase is responsible for crystalline, high carrier mobility, porous structure for mass transport, thermal and mechanical stabilities. In the case of application for APEMFC, polyvinyl

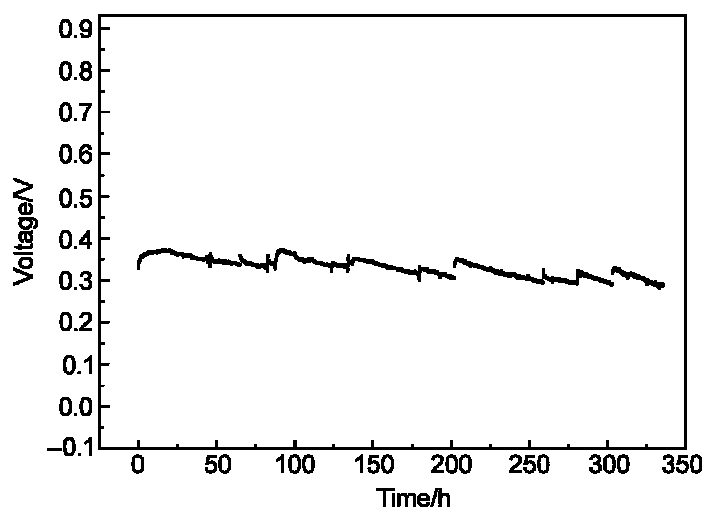

Fig.12 Lifetime of air breathing Pt-free alkaline direct ethanol fuel cell with $\mathrm{PBI} / \mathrm{KOH}$ at $60{ }^{\circ} \mathrm{C}^{206}$ anode catalyst: $40 \% \mathrm{Pd} / \mathrm{C}$, cathode catalyst: $40 \% \mathrm{MnO}_{2} / \mathrm{C}$, constant current density: $25 \mathrm{~mA} \cdot \mathrm{cm}^{-2}$ 


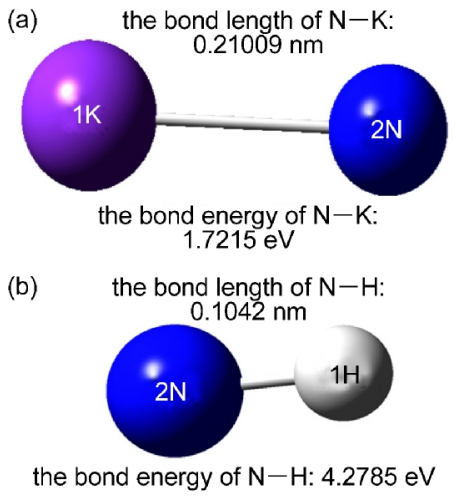

Fig.13 Bond lengths and bond energies of $N-K$ (a) and $N-H$ (b) calculated by density functional theory ${ }^{206}$

alcohol and chitosan usually act as the organic polymer phase, while $\mathrm{KOH}$ is the second inorganic phase. ${ }^{208-211}$ Sometimes, in order to further optimize mechanical property and the porous structure for better transport properties, the third inorganic phase such as $\mathrm{SiO}_{2},{ }^{212}$ carbon nanotubes, ${ }^{213}$ layered double hydroxide, ${ }^{214}$ graphene nanosheets, or organic polymer ${ }^{215-217}$ etc. was also introduced into the composite membrane. For example, hybrid membrane containing graphene nanosheets and poly(vinyl alcohol) (PVA) was designed and prepared for alkaline direct methanol fuel cell, and the transport property of hybrid membrane was explored. The results suggested that graphene nanosheets were uniformly dispersed, resulting in continuous, well-connected and tortuous ion transport channels. The addition of only $0.7 \%$ graphene nanosheets into PVA matrix brought about the increase by $126 \%$ in ionic conductivity and $55 \%$ reduction in methanol permeability, while the loading of $1.4 \%$ graphene increased by $73 \%$ the tensile strength. For special consideration into high ionic conductivity, the further quaternization of the third phase was also performed. ${ }^{218}$ Chitosan is a main derivative of chitin and it can be mainly obtained by deacetylating chitin with an alkaline treatment. Although it is a weak-alkaline polymer, its ionic conductivity can be close to $0.001 \mathrm{~S} \cdot \mathrm{cm}^{-1}$ after full hydration, which is still not high enough for fuel cell. Therefore, chitosan/KOH hybrid membrane for alkaline fuel cell was preliminarily prepared and evaluated. ${ }^{219,220}$ The obtained membrane had a three-layer structure, consisting of a porous intermediate layer and two crosslinked solid surface layers. After being hydrated for $1 \mathrm{~h}$ at room temperature, this membrane showed ionic conductivity near $0.01 \mathrm{~S}$. $\mathrm{cm}^{-2}$.

\section{Conclusions and prospect}

Significant progresses about alkaline polymer electrolyte membrane for APEMFC have been made: up to now, the highest peak power density of $\mathrm{H}_{2} / \mathrm{O}_{2}$ APEMFC with irradiation-grafting QAEM was as high as $823 \mathrm{~mW} \cdot \mathrm{cm}^{-2}$ at $60{ }^{\circ} \mathrm{C}$, and in situ durability tests for $520 \mathrm{~h}$ of commercial Tokuyama ${ }^{\circledR}$ membrane were achieved too. Among various alkaline polymer electrolytes, quaternized anion exchange membrane was still the most promising membrane for APEMFC, although the thermal stability and alkali-resistance need be further enhanced; metal-cation-based anion exchange membrane and organic/inorganic hybrid membrane may be fit for high temperature APEMFC due to their high stability. ${ }^{221}$

On the other hand, there still existed some challenges to deal with: (i) soluble anion exchange ionomer electrode binder similar to commercial Nafion ${ }^{\circledR}$ soultion for building triple-phase interface may be one of the effective solutions to achieve better performances of metal-cation-free APEMFC, however, the corresponding investigation need be intensively carried out because there still is not authoritative alkaline counterpart to Nafion ${ }^{\circledR}$ solution for the moment; (ii) although many synthesis strategies of various alkaline polymer membranes were deep and widely investigated, however, there is still no alkaline benchmark counterpart to Nafion ${ }^{\circledR}$ membrane for PEMFC. Additionally, the corresponding in situ durability tests for APEMFC are still scarce and not very satisfying, therefore, the corresponding investigation will be a continuous hot topic in the future. After all, in situ durability is final standard to judge whether an alkaline polymer membrane is suitable for fuel cell application.

\section{References}

(1) Hou, H.; Di Vona, M. L.; Liu, X.; Sgreccia, E.; Chailan, J. F.; Knauth, P. Int. J. Hydrog. Energy 2013, 38, 3346. doi: 10.1016/ j.ijhydene.2012.12.019

(2) Hou, H.; Di Vona, M. L.; Knauth, P. ChemSusChem 2011, 4, 1526. doi: 10.1002/cssc.v4.11

(3) Hou, H.; Di Vona, M. L.; Knauth, P. J. Membr. Sci. 2012, 423423,113 .

(4) Jiang, Q.; Jiang, L.; Hou, H.; Qi, J.; Wang, S.; Sun, G. J. Phys. Chem. C 2010, 114, 19714. doi: 10.1021/jp1039755

(5) Yin, J.; Shan, S.; Ng, M. S.; Yang, L.; Mott, D.; Fang, W.; Kang, N.; Luo, J.; Zhong, C. Langmuir 2013, 29, 9249. doi: $10.1021 / \mathrm{la} 401839 \mathrm{~m}$

(6) Robertson, N. J.; Kostalik, H. A., IV; Clark, T. J.; Mutolo, P. F.; Abruna, H. D.; Coates, G. W. J. Am. Chem. Soc. 2010, 132, 3400. doi: $10.1021 / \mathrm{ja} 908638 \mathrm{~d}$

(7) Liu, J. P.; Ye, J. Q.; Xu, C. W.; Jiang, S. P.; Tong, Y. X. Electrochem. Commun. 2007, 9, 2334. doi: 10.1016/j. elecom.2007.06.036

(8) Wu, X.; Scott, K. J. Power Sources 2012, 206, 14. doi: 10.1016/j.jpowsour.2011.12.052

(9) Li, X.; Popov, B. N.; Kawahara, T.; Yanagi, H. J. Power Sources 2011, 196, 1717. doi: 10.1016/j.jpowsour.2010.10.018

(10) Xiang, F.; Shen, P. K. Acta Phys. -Chim. Sin. 2009, 25, 1933. [方 翔, 沈培康. 物理化学学报, 2009, 25, 1933.] doi: 10.3866/PKU.WHXB20090918

(11) Yang, Y. Y.; Ren, J.; Zhang, H. X.; Zhou, Z. Y.; Sun, S. G.; Cai, W. B. Langmuir 2013, 29, 1709. doi: 10.1021/1a305141q

(12) Ma, L.; He, H.; Hsu, A.; Chen, R. J. Power Sources 2013, 241, 696. doi: 10.1016/j.jpowsour.2013.04.051

(13) Ohyama, J.; Sato, T.; Satsuma, A. J. Power Sources 2013, 225, 
311. doi: 10.1016/j.jpowsour.2012.10.051

(14) Varcoe, J. R.; Slade, R. C. T.; Wright, G. L.; Chen, Y. J. Phys. Chem. B 2006, 110, 21041. doi: 10.1021/jp064898b

(15) Zhang, Z.; Xin, L.; Li, W. Int. J. Hydrog. Energy 2012, 37, 9292.

(16) Guo, J.; Zhou, J.; Chu, D.; Chen, R. J. Phys. Chem. C 2013, 117, 4006. doi: 10.1021/jp310655y

(17) Wang, Z.; Xin, L.; Zhao, X.; Qiu, Y.; Zhang, Z.; Baturina, O. A.; Li, W. Renewable Energy 2014, 62, 556. doi: 10.1016/j. renene.2013.08.005

(18) Mamlouk, M.; Kumar, S. M. S.; Gouerec, P.; Scott, K. J. Power Sources 2011, 196, 7594. doi: 10.1016/j. jpowsour.2011.04.045

(19) Qiao, J.; Xu, L.; Liu, Y.; Xu, P.; Shi, J.; Liu, S.; Tian, B. Electrochim. Acta 2013, 96, 298. doi: 10.1016/j. electacta.2013.02.030

(20) Heli, H.; Jafarian, M.; Mahjani, M. G.; Gobal, F. Electrochim. Acta 2004, 49, 4999. doi: 10.1016/j.electacta.2004.06.015

(21) Sakamoto, T.; Asazawa, K.; Yamada, K.; Tanaka, H. Catalysis Today 2011, 164, 181. doi: 10.1016/j.cattod.2010.11.012

(22) Verma, A.; Jha, A. K.; Basu, S. J. Power Sources 2005, 141, 30. doi: 10.1016/j.jpowsour.2004.09.005

(23) Rao, C. V.; Ishikawa, Y. J. Phys. Chem. C 2012, 116, 4340. doi: 10.1021/jp210840a

(24) Huang, D.; Zhang, B.; Zhang, Y.; Zhan, F.; Xu, X.; Shen, Y.; Wang, M. J. Mater. Chem. A 2013, 1, 1415. doi: 10.1039/ c2ta00552b

(25) Yang, S.; Feng, X.; Wang, X.; Müllen, K. Angew. Chem. Int. Edit. 2011, 50, 5339. doi: 10.1002/anie.201100170

(26) Chen, P.; Xiao, T.; Qian, Y.; Li, S.; Yu, S. Adv. Mater. 2013, 25, 3192. doi: 10.1002/adma.201300515

(27) Li, Y. S.; Zhao, T. S. Int. J. Hydrog. Energy 2012, 37, 15334. doi: 10.1016/j.ijhydene.2012.07.119

(28) Wang, Y.; Li, L.; Hu, L.; Zhuang, L.; Lu, J. T.; Xu, B. Q. Electrochem. Commun. 2003, 5, 662. doi: 10.1016/S1388-2481 (03)00148-6

(29) Bahrami, H.; Faghri, A. J. Power Sources 2012, 218, 286. doi: 10.1016/j.jpowsour.2012.06.057

(30) Bambagioni, V.; Bianchini, C.; Marchionni, A.; Filippi, J.; Vizza, F.; Teddy, J.; Serp, P.; Zhiani, M. J. Power Sources 2009, 190, 241. doi: 10.1016/j.jpowsour.2009.01.044

(31) Ilie, A.; Simoes, M.; Baranton, S.; Coutanceau, C.; Martemianov, S. J. Power Sources 2011, 196, 4965. doi: 10.1016/j.jpowsour.2011.02.003

(32) Zhang, Z.; Xin, L.; Li, W. Appl. Catal. B: Environ. 2012, 119120,40 .

(33) Bartrom, A. M.; Haan, J. L. J. Power Sources 2012, 214, 68. doi: 10.1016/j.jpowsour.2012.04.032

(34) Suzuki, S.; Muroyama, H.; Matsui, T.; Eguchi, K. J. Power Sources 2012, 208, 257. doi: 10.1016/j.jpowsour.2012.02.043

(35) Sakamoto, T.; Asazawa, K.; Chinchilla, J. S.; Martinez, U.;
Halevi, B.; Atanassov, P.; Strasser, P.; Tanaka, H. J. Power Sources 2014, 247, 605. doi: 10.1016/j.jpowsour.2013.08.107

(36) Qiao, J.; Fu, J.; Liu, L.; Zhang, J.; Xie, J.; Li, G. Solid State Ionics 2012, 214, 6. doi: 10.1016/j.ssi.2012.02.059

(37) Xia, Z.; Yuan, S.; Jiang, G.; Guo, X.; Fang, J.; Liu, L.; Qiao, J.; Yin, J. J. Membr. Sci. 2012, 390-391, 152.

(38) Couture, G.; Alaaeddine, A.; Boschet, F.; Ameduri, B. Prog. Polym. Sci. 2011, 36, 1521. doi: 10.1016/j. progpolymsci.2011.04.004

(39) Merle, G.; Wessling, M.; Nijmeijer, K. J. Membr. Sci. 2011, 377, 1. doi: 10.1016/j.memsci.2011.04.043

(40) Zha, Y.; Miller, M. L. D.; Johnson, Z. D.; Hickner, M. A.; Tew, G. N. J. Am. Chem. Soc. 2012, 134, 4493. doi: 10.1021/ ja211365r

(41) Huo, S.; Deng, H.; Chang, Y.; Jiao, K. Int. J. Hydrog. Energy 2012, 37, 18389. doi: 10.1016/j.jhydene.2012.09.074

(42) Kang, S.; Jung, D.; Shin, J.; Lim, S.; Kim, S. K.; Shul, Y.; Peck, D. H. J. Membr. Sci. 2013, 447, 36. doi: 10.1016/j. memsci.2013.07.005

(43) Fujimoto, C.; Kim, D. S.; Hibbs, M.; Wrobleski, D.; Kim, Y. S. J. Membr. Sci. 2012, 423-424, 438.

(44) Piana, M.; Boccia, M.; Filpi, A.; Flammia, E.; Miller, H. A.; Orsini, M.; Salusti, F.; Santiccioli, S.; Ciardelli, F.; Pucci, A. J. Power Sources 2010, 195, 5875. doi: 10.1016/j. jpowsour.2009.12.085

(45) Li, Y. S.; Zhao, T. S.; Liang, Z. X. J. Power Sources 2009, 190, 223. doi: 10.1016/j.jpowsour.2009.01.055

(46) Deng, H.; Huo, S.; Chang, Y.; Zhou, Y.; Jiao, K. Int. J. Hydrog. Energy 2013, 38, 6509. doi: 10.1016/j.ijhydene.2013.03.045

(47) Jung, H.; Fujii, K.; Tamaki, T.; Ohashi, H.; Ito, T.; Yamaguchi, T. J. Membr. Sci. 2011, 373, 107. doi: 10.1016/j. memsci.2011.02.044

(48) Gu, S.; Cai, R.; Yan, Y. Chem. Commun. 2011, 47, 2856. doi: 10.1039/c0cc04335d

(49) Gu, S.; Cai, R.; Luo, T.; Chen, Z.; Sun, M.; Liu, Y.; He, G.; Yan, Y. Angew. Chem. Int. Edit. 2009, 48, 6499. doi: 10.1002/ anie.v48:35

(50) Yazicigil, Z.; Oztekin, Y. Desalination 2006, 190, 71. doi: 10.1016/j.desal.2005.07.016

(51) Grekovich, A. L.; Mikhelson, K. N. J. Electroanal. 2002, 14, 1391. doi: 10.1002/1521-4109(200211)14:19/20<1391::AIDELAN1391>3.0.CO;2-S

(52) Koo, J. S.; Kwak, N. S.; Hwang, T. S. J. Membr. Sci. 2012, 423-424, 293.

(53) Wang, Z. X.; Luo, Y. B.; Yu, P. J. Membr. Sci. 2006, 280, 134. doi: 10.1016/j.memsci.2006.01.015

(54) Hwang, G. J.; Ohya, H. J. Membr. Sci. 1997, 32, 55.

(55) Zhang, M.; Kim, H. K.; Chalkova, E.; Mark, F.; Lvov, S. N.; Chung, T. C. M. Macromolecules 2011, 44, 5937. doi: 10.1021/ ma200836d

(56) Noonan, K. J. T.; Hugar, K. M.; Kostalik, H. A., IV; 
Lobkovsky, E. B.; Abrun, H. D.; Coates, G. W. J. Am. Chem. Soc. 2012, 134, 18161. doi: 10.1021/ja307466s

(57) He, Q.; Ren, X. J. Power Sources 2012, 220, 373. doi: 10.1016/ j.jpowsour.2012.07.039

(58) Kim, J. H.; Kim, H. K.; Hwang, K. T.; Lee, J. Y. Int. J. Hydrog Energy 2010, 35, 768. doi: 10.1016/j.ijhydene.2009.10.100

(59) Prakash, G. K. S.; Krause, F. C.; Viva, F. A.; Narayanan, S. R.; Olah, G. A. J. Power Sources 2011, 196, 7967. doi: 10.1016/j. jpowsour.2011.05.056

(60) Leng, Y. J.; Chen, G.; Mendoza, A. J.; Tighe, T. B.; Hickner, M. A.; Wang, C. Y. J. Am. Chem. Soc. 2012, 134, 9054. doi: $10.1021 / \mathrm{ja} 302439 \mathrm{z}$

(61) Li, Y. S.; He, Y. L.; Yang, W. W. Int. J. Hydrog. Energy 2013, 38, 13427. doi: 10.1016/j.ijhydene.2013.07.042

(62) Wang, X.; McClure, J. P.; Fedkiw, P. S. Electrochim. Acta 2012, 79, 126. doi: 10.1016/j.electacta.2012.06.098

(63) Giffin, G. A.; Lavina, S.; Pace, G.; Di Noto V. J. Phys. Chem. C 2012, 116, 23965. doi: 10.1021/jp3094879

(64) Follain, N.; Roualdes, S.; Marais, S.; Frugier, J.; Reinholdt, M. J. Phys. Chem. C 2012, 116, 8510. doi: 10.1021/jp2109835

(65) Scott, K.; Yu, E.; Vlachogiannopoulos, G.; Shivare, M.; Duteanu, N. J. Power Sources 2008, 175, 452. doi: 10.1016/j. jpowsour.2007.09.027

(66) Frenzel, I.; Holdik, H.; Stamatialis, D.; Pourcelly, G.; Wessling, M. J. Membr. Sci. 2005, 261, 49. doi: 10.1016/j. memsci.2005.03.031

(67) Aarnio, A. S.; Hietala, S.; Rauhala, T.; Kallio, T. J. Power Sources 2011, 196, 6153. doi: 10.1016/j.jpowsour.2011.03.028

(68) Li, Y. S.; Zhao, T. S.; Yang, W. W. Int. J. Hydrog. Energy 2010, 35,5656

(69) Matsuoka, K.; Iriyama, Y.; Abe, T.; Matsuoka, M.; Ogumi, Z. J. Power Sources 2005, 150, 27. doi: 10.1016/j. jpowsour.2005.02.020

(70) Li, Y. S.; Zhao, T. S.; Liang, Z. X. J. Power Sources 2009, 187, 387. doi: 10.1016/j.jpowsour.2008.10.132

(71) Li, Y. S.; Zhao, T. S. Int. J. Hydrog. Energy 2011, 36, 7707. doi: 10.1016/j.ijhydene.2011.03.090

(72) Li, Y. S.; Zhao, T. S. Int. J. Hydrog. Energy 2012, 37, 4413. doi: 10.1016/j.ijhydene.2011.11.086

(73) Shen, S. Y.; Zhao, T. S.; Wu, Q. X. Int. J. Hydrog. Energy 2012, 37, 575. doi: 10.1016/j.ijhydene.2011.09.077

(74) Suzuki, S.; Muroyama, H.; Matsui, T.; Eguchi, K. Electrochim. Acta 2013, 88, 552. doi: 10.1016/j.electacta.2012.10.105

(75) Li, Y. S.; Zhao, T. S.; Chen, R. J. Power Sources 2011, 196, 133. doi: 10.1016/j.jpowsour.2010.06.111

(76) Cao, Y. C.; Wang, X.; Scott, K. J. Power Sources 2012, 201, 226. doi: 10.1016/j.jpowsour.2011.10.113

(77) Price, S. C.; Ren, X.; Jackson, A. C.; Ye, Y.; Elabd, Y. A.; Beyer, F. L. Macromolecules 2013, 46, 7332. doi: 10.1021/ ma400995n

(78) Tripathi, B. P.; Kumar, M.; Shahi, V. K. J. Membr. Sci. 2010,
360, 90. doi: 10.1016/j.memsci.2010.05.005

(79) Tanaka, M.; Koike, M.; Miyatake, K.; Watanabe, M. Macromolecules 2010, 43, 2657. doi: 10.1021/ma902479d

(80) Li, N.; Zhang, Q., Wang, C.; Lee, Y. M.; Guiver, M. D. Macromolecules 2012, 45, 2411. doi: 10.1021/ma202681z

(81) Wang, J.; Wang, J.; Li, S.; Zhang, S. J. Membr. Sci. 2011, 368, 246. doi: 10.1016/j.memsci.2010.11.058

(82) Mamlouk, M.; Scott, K.; Horsfall, J. A.; Williams, C. Int. J. Hydrog. Energy 2011, 36, 7191. doi: 10.1016/j. ijhydene.2011.03.074

(83) Zhang, J.; Qiao, J.; Jiang, G.; Liu, L.; Liu, Y. J. Power Sources 2013, 240, 359. doi: 10.1016/j.jpowsour.2013.03.162

(84) Tanaka, M.; Koike, M.; Miyatake, K.; Watanabe, M. Polym. Chem. 2011, 2, 99. doi: 10.1039/c0py00238k

(85) Sun, L.; Guo, J.; Zhou, J.; Xu, Q.; Chu, D.; Chen, R. J. Power Sources 2012, 202, 70. doi: 10.1016/j.jpowsour.2011.11.023

(86) Lee, K. M.; Wycisk, R.; Litt, M.; Pintauro, P. N. J. Membr. Sci. 2011, 383, 254. doi: 10.1016/j.memsci.2011.08.062

(87) Maesa, A. M.; Pandeya, T. P.; Vandiver, M. A.; Lundquist, L. K.; Yang, Y.; Horan, J. L.; Krosovsky, A.; Liberatore, M. W.; Seifert, S.; Herring, A. M. Electrochim. Acta 2013, 110, 260. doi: 10.1016/j.electacta.2013.04.033

(88) Zeng, L.; Tang, Z. K.; Zhao, T. S. Appl. Energy 2014, 115, 405. doi: 10.1016/j.apenergy.2013.11.039

(89) Li, X.; Yu, Y.; Liu, Q.; Meng, Y. ACS Appl. Mater. Interfaces 2012, 4, 3627. doi: 10.1021/am3007005

(90) Zhou, J.; Guo, J.; Chu, D.; Chen, R. J. Power Sources 2012, 219, 272. doi: 10.1016/j.jpowsour.2012.07.051

(91) Zeng, Q. H.; Liu, Q. L.; Broadwell, I.; Zhu, A. M.; Xiong, Y.; Tu, X. P. J. Membr. Sci. 2010, 349, 237. doi: 10.1016/j. memsci.2009.11.051

(92) Seo, D. W.; Lim, Y. D.; Hossain, M. A.; Lee, S. H.; Lee, H. C.; Jang, H. H.; Choi, S. Y.; Kim, W. G. Int. J. Hydrog. Energy 2012, 38, 579.

(93) Abuin, G. C.; Nonjola, P.; Franceschini, E. A.; Izraelevitch, F. H.; Mathe, M. K.; Corti, H. R. Int. J. Hydrog. Energy 2010, 35, 5849. doi: 10.1016/j.ijhydene.2009.12.128

(94) Seo, D. W.; Hossain, M. A.; Lee, D. H.; Lim, Y. D.; Lee, S. H.; Lee, H. C.; Hong, T. W.; Kim, W. G. Electrochim. Acta 2012, 86, 360. doi: 10.1016/j.electacta.2012.04.065

(95) Zhao, Z.; Gong, F.; Zhang, S.; Li, S. J. Power Sources 2012, 218, 368. doi: 10.1016/j.jpowsour.2012.07.011

(96) Zarrin, H.; Wu, J.; Fowler, M.; Chen, Z. J. Membr. Sci. 2012, 394-395, 193.

(97) Wang, G.; Weng, Y.; Chu, D.; Chen, R.; Xie, D. J. Membr. Sci. 2009, 332, 63 .

(98) Hossain, M. A.; Lim, Y.; Lee, S.; Jang, H.; Choi, S.; Jeon, Y.; Lim, J.; Kim, W. G. Int. J. Hydrog. Energy 2014, 39, 2731.

(99) Li, X.; Yu, Y.; Liu, Q.; Meng, Y. J. Membr. Sci. 2013, 436, 202. doi: 10.1016/j.memsci.2013.02.041

(100) Tanaka, M.; Fukasawa, K.; Nishino, E.; Yamaguchi, S.; 
Yamada, K.; Tanaka, H.; Bae, B.; Miyatake, K.; Watanabe, M. J. Am. Chem. Soc. 2011, 133, 10646. doi: 10.1021/ja204166e

(101) Park, D. Y.; Kohl, P. A.; Beckham, H. W. J. Phys. Chem. C 2013, 117, 15468. doi: 10.1021/jp311987v

(102) Zeng, L.; Zhao, T. S. Electrochem. Commun. 2013, 34, 278. doi: 10.1016/j.elecom.2013.07.015

(103) Mahendiravarman, E.; Sangeetha, D. Int. J. Hydrog. Energy 2013, 38, 2471.

(104) Yan, X.; He, G.; Gu, S.; Wu, X.; Du, L.; Zhang, H. J. Membr. Sci. 2011, 375, 204. doi: 10.1016/j.memsci.2011.03.046

(105) Yan, X.; He, G.; Gu, S.; Wu, X.; Du, L.; Wang, Y. Int. J. Hydrog. Energy 2012, 37, 5216. doi: 10.1016/j. ijhydene.2011.12.069

(106) Yan, X.; Wang, Y.; He, G.; Hu, Z.; Wu, X. Int. J. Hydrog. Energy 2012, 38, 7964;

(107) Lu, W.; Shao, Z.; Zhang, G.; Li, J.; Zhao, Y.; Yi, B. Solid State Ionics 2013, 245-246, 8.

(108) Lu, W.; Shao, Z.; Zhang, G.; Zhao, Y.; Li, J.; Yi, B. Int. J. Hydrog. Energy 2013, 38, 9285. doi: 10.1016/j. ijhydene.2013.05.070

(109) Vinodh, R.; Purushothaman, M.; Sangeetha, D. Int. J. Hydrog. Energy 2011, 36, 291.

(110) Wang, X.; Li, M.; Golding, B. T.; Sadeghi, M.; Cao, Y.; Yu, E. H.; Scott, K. Int. J. Hydrog. Energy 2011, 36, 10022. doi: 10.1016/j.ijhydene.2011.05.054

(111) Jasti, A.; Prakash, S.; Shahi, V. K. J. Membr. Sci. 2013, 428, 470. doi: 10.1016/j.memsci.2012.11.016

(112) Han, J.; Peng, H.; Pan, J.; Wei, L.; Li, G.; Chen, C.; Xiao, L.; Lu, J.; Zhuang, L. ACS Appl. Mater. Interfaces 2014, 5, 13405.

(113) Mamlouk, M.; Scott, K. J. Power Sources 2012, 211, 140146. doi: 10.1016/j.jpowsour.2012.03.100

(114) Luo, Y.; Guo, J.; Liu, Y.; Shao, Q.; Wang, C.; Chu, D. J. Membr. Sci. 2012, 423-424, 209.

(115) Danks, T. N.; Slade, R. C. T.; Varcoe, J. R. J. Mater. Chem. 2003, 13, 712. doi: 10.1039/b212164f

(116) Ko, B. S.; Sohn, J. Y.; Shin, J. Polymer 2012, 53, 4652. doi: 10.1016/j.polymer.2012.08.002

(117) Fang, J.; Yang, Y.; Lu, X.; Ye, M.; Li, W.; Zhang, Y. Int. J. Hydrog. Energy 2012, 37, 594. doi: 10.1016/j. ijhydene.2011.09.112

(118) Varcoe, J. R.; Slade, R. C. T. Eletrochem. Commun. 2006, 8, 839. doi: $10.1016 /$ j.elecom.2006.03.027

(119) Liu, H.; Yang, S.; Wang, S.; Fang, J.; Jiang, L.; Sun, G. J. Membr. Sci. 2011, 369, 277. doi: 10.1016/j. memsci.2010.12.002

(120) Liu, H.; Wang, S. L.; Jiang, L. H.; Sun, G. Q. Scienta Sinica Chimica 2011, 41, 1857. [柳 鹤, 王素力, 姜鲁华, 孙公权. 中国科学: 化学, 2011, 41, 1857.] doi: 10.1360/032011-590

(121) Zikewski, J. P.; Mudri, N. H.; Varcoe, J. R. Phys. Chem. 2013, $89,64$.

(122) Poynton, S. D.; Kizewski, J. P.; Slade, R. C. T.; Varcoe, J. R.
Solid State Ionics 2010, 181, 219. doi: 10.1016/j. ssi.2009.01.019

(123) Mamlouk, M.; Horsfall, J. A.; Williams, C.; Scott, K. Int. J. Hydrog. Energy 2012, 37, 11912. doi: 10.1016/j. ijhydene.2012.05.117

(124) Ko, B. S.; Sohn, J. Y.; Nho, Y. C.; Shin, J. Nuclear Instruments Methods in Physics Research B 2011, 269, 2509. doi: 10.1016/ j.nimb.2011.07.022

(125) Ameduri, B. Chem. Rev. 2009, 109, 6632. doi: 10.1021/ cr800187m

(126) Mamlouk, M.; Horsfall, J. A.; Williams, C.; Scott, K. Int. J. Hydrog. Energy 2012, 37, 11912. doi: 10.1016/j. ijhydene.2012.05.117

(127) Sherazi, T. A.; Sohn, J. Y.; Lee, Y. M.; Guiver, M. D. J. Membr Sci. 2013, 441, 148. doi: 10.1016/j.memsci.2013.03.053

(128) Hu, J.; Zhang, C.; Jiang, L.; Fang, S.; Zhang, X.; Wang, X.; Meng, Y. J. Power Sources 2014, 248, 831. doi: 10.1016/j. jpowsour.2013.09.099

(129) Hu, J.; Zhang, C.; Cong, J.; Toyoda, H.; Nagatsu, M.; Meng, Y. J. Power Sources 2011, 196, 4483. doi: 10.1016/j. jpowsour.2011.01.034

(130) Lin, X.; Liu, Y.; Poynton, S. D.; Ong, A. L.; Varcoe, J. R.; Wu, L.; Li, Y.; Liang, X.; Li, Q.; Xu, T. J. Power Sources 2013, 233, 259. doi: 10.1016/j.jpowsour.2013.01.059

(131) Sudre, G.; Inceoglu, S.; Cotanda, P.; Balsara, N. P. Macromolecules 2013, 46, 1519. doi: 10.1021/ma302357k

(132) Hu, J.; Meng, Y.; Zhang, C.; Fang, S. Thin Solid Films 2011, 519, 2155. doi: 10.1016/j.tsf.2010.11.028

(133) Zhang, C.; Hu, J.; Cong, J.; Zhao, Y.; Shen, W.; Toyoda, H.; Nagatsu, M.; Meng, Y. J. Power Sources 2011, 196, 5386. doi: 10.1016/j.jpowsour.2011.02.073

(134) Zhang, Y.; Fang, J.; Wu, Y.; Xu, H.; Chi, X.; Li, W., Yang, Y.; Yan, G.; Zhuang, Y. J. Colloid Interface Sci. 2102, 381, 59.

(135) Xu, H.; Fang, J.; Guo, M.; Lu, X.; Wei, X.; Tu, S. J. Membr. Sci. 2010, 354, 206. doi: 10.1016/j.memsci.2010.02.028

(136) Lu, W.; Shao, Z. G.; Zhang, G.; Zhao, Y.; Yi, B. J. Power Sources 2014, 248, 905. doi: 10.1016/j.jpowsour.2013.08.141

(137) Wu, L.; Zhou, G.; Liu, X.; Zhang, Z.; Li, C.; Xu, T. J. Membr. Sci. 2011, 371, 155. doi: 10.1016/j.memsci.2011.01.036

(138) Lin, X.; Gong, M.; Liu, Y.; Wu, L.; Li, Y.; Liang, X.; Li, Q.; Xu, T. J. Membr. Sci. 2013, 425-426, 190.

(139) Henkensmeier, D.; Cho, H.; Brela, M.; Michalak, A.; Dyck, A.; Germe, W.; Duong, N. M. H.; Jang, J. H.; Kim, H. J.; Woo, N. S.; Lim, T. H. Int. J. Hydrog. Energy 2014, 39, 2842.

(140) Hou, H.; Wang, S.; Liu, H.; Sun, L.; Jin, W.; Jing, M.; Jiang, L.; Sun, G. Int. J. Hydrog. Energy 2011, 35, 11955.

(141) Wang, J.; He, R.; Che, Q. J. Colloid Interface Sci. 2011, 361, 219. doi: 10.1016/j.jcis.2011.05.039

(142) Wan, Y.; Peppley, B.; Creber, K. A. M.; Bui, V. T. J. Power Sources 2010, 195, 3785. doi: 10.1016/j.jpowsour.2009.11.123

(143) Wang, J.; Wang, J.; Zhang, S. J. Membr. Sci. 2012, 415-416, 
205.

(144) Zhang, Q.; Zhang, Q.; Wang, J.; Zhang, S.; Li, S. Polymer 2010, 51, 5407. doi: 10.1016/j.polymer.2010.09.049

(145) Qiu, B.; Lin, B.; Si, Z.; Qiu, L.; Chu, F.; Zhao, J.; Yan, F. J. Power Sources 2012, 217, 329. doi: 10.1016/j. jpowsour.2012.06.041

(146) Kim, D.; Labouriau, A.; Guiver, M. D.; Kim, Y. Chem. Mater. 2011, 23, 3795. doi: 10.1021/cm2016164

(147) Yan, X.; Gu, S.; He, G.; Wu, X.; Benziger, J. J. Power Sources 2014, 250, 90. doi: 10.1016/j.jpowsour.2013.10.140

(148) Liu, L.; Li, Q.; Dai, J.; Wang, H.; Jin, B.; Bai, R. J. Membr. Sci. 2014, 453, 52. doi: 10.1016/j.memsci.2013.10.054

(149) Zhang, H.; Ohashi, H.; Tamaki, T.; Yamaguchi, T. J. Phys. Chem. C 2012, 116, 7650. doi: 10.1021/jp211084b

(150) Ye, Y.; Sharick, S.; Davis, E. M.; Winey, K. I.; Elabd, Y. A ACS Macro. Lett. 2013, 2, 575. doi: 10.1021/mz400210a

(151) Ye, Y.; Elabd, Y. A. Macromolecules 2011, 44, 8494. doi: $10.1021 / \mathrm{ma} 201864 \mathrm{u}$

(152) Lin, B.; Qiu, L.; Lu, J.; Yan, F. Chem. Mater. 2010, 22, 6718. doi: $10.1021 / \mathrm{cm} 102957 \mathrm{~g}$

(153) Lin, B.; Qiu, L.; Qiu, B.; Peng, Y.; Yan, F. Macromolecules 2011, 44, 9642. doi: 10.1021/ma202159d

(154) Guo, M.; Fang, J.; Xu, H.; Li, W.; Lu, X.; Lan, C.; Li, K. J. Membr. Sci. 2010, 362, 97. doi: 10.1016/j. memsci.2010.06.026

(155) Li, X.; Yu, Y.; Liu, Q.; Meng, Y. Int. J. Hydrog. Energy 2013, 38, 11067. doi: 10.1016/j.ijhydene.2013.01.006

(156) Hu, Q.; Shang, Y.; Wang, Y.; Xu, M.; Wang, S.; Xie, X. G.; Liu, Y.; Zhang, H.; Wang, J.; Mao, Z. Int. J. Hydrog. Energy 2012, 37, 12659. doi: 10.1016/j.ijhydene.2012.05.077

(157) Chen, D.; Hickner, M. A. Macromolecules 2013, 46, 9270. doi $10.1021 / \mathrm{ma} 401620 \mathrm{~m}$

(158) Yan, J.; Hickner, M. A. Macromolecules 2010, 43, 2349. doi: $10.1021 / \mathrm{ma} 902430 \mathrm{y}$

(159) Xu, S.; Zhang, G.; Zhang, Y.; Zhao, C.; Ma, W.; Sun, H.; Zhang, N.; Zhang, L.; Jiang, H.; Na, H. J. Power Sources 2012, 209, 228. doi: 10.1016/j.jpowsour.2012.02.076

(160) Katzfub, A.; Gogel, V.; Jorissen, L.; Kerres, J. J. Membr. Sci. 2013, 425-426, 131.

(161) Tanaka, M.; Koike, M.; Miyatake, K.; Watanabe, M. Polym. Chem. 2011, 2, 99. doi: 10.1039/c0py00238k

(162) Wang, W.; Wang, S.; Li, W.; Xie, X.; Lv, Y. Int. J. Hydrog. Energy 2013, 38, 11045. doi: 10.1016/j.ijhydene.2013.03.166

(163) Rao, A. H. N.; Thankamony, R. L.; Kim, H. J.; Nam, S.; Kim, T. H. Polymer 2013, 54, 111. doi: 10.1016/j.polymer. 2012.11.023

(164) Li, C.; Wang, S.; Wang, W.; Xie, X.; Lv, Y.; Deng, C. Int. J. Hydrog. Energy 2013, 38, 11038.

(165) Li, N.; Leng, Y.; Hickner, M. A.; Wang, C. Y. J. Am. Chem. Soc. 2013, 135, 10124. doi: 10.1021/ja403671u

(166) Zhao, C. H.; Gong, Y.; Liu, Q. L.; Zhang, Q. G.; Zhu, A. M.
Int. J. Hydrog. Energy 2012, 37, 11383. doi: 10.1016/j. ijhydene.2012.04.163

(167) Shen, K.; Pang, J.; Feng, S.; Wang, Y.; Jiang, Z. J. Membr. Sci. 2013, 440, 20.

(168) Lin, X.; Wu, L.; Liu, Y.; Ong, A. L.; Poynton, S. D.; Varcoe, J. R.; Xu, T. J. Power Sources 2012, 217, 373. doi: 10.1016/j. jpowsour.2012.05.062

(169) Lin, X.; Liang, X.; Poynton, S. D.; Varcoe, J. R.; Ong, A. L.; Ran, J.; Li, Y.; Li, Q.; Xu, T. J. Membr. Sci. 2013, 443, 193. doi: 10.1016/j.memsci.2013.04.059

(170) Ye, L.; Zhai, L.; Fang, J.; Liu, J.; Li, C.; Guan, R. Solid State Ionics 2013, 240, 1. doi: 10.1016/j.ssi.2013.03.019

(171) Yang, C. C.; Chiu, S. S.; Kuo, S. C.; Liou, T. H. J. Power Sources 2012, 199, 37. doi: 10.1016/j.jpowsour.2011.10.020

(172) Wang, J.; Li, S.; Zhang, S. Macromolecules 2010, 43, 3890. doi: 10.1021/ma100260a

(173) Chen, D.; Hickner, M. A. ACS Appl. Mater. Interfaces 2012, 4, 5775. doi: $10.1021 / \mathrm{am} 301557 \mathrm{w}$

(174) Long, H.; Kim, K.; Pivovar, B. S. J. Phys. Chem. C 2012, 116, 9419. doi: 10.1021/jp3014964

(175) Kim, D. S.; Fujimoto, C. H.; Hibbs, M. R.; Labouriau, A.; Choe, Y. K.; Kim, Y. S. Macromolecules 2013, 46, 7826. doi: $10.1021 / \mathrm{ma} 401568 \mathrm{f}$

(176) Luo, Y.; Guo, J.; Wang, C.; Chu, D. Electrochem. Commun. 2012, 16, 65. doi: 10.1016/j.elecom.2012.01.005

(177) Pan, J.; Chen, C.; Zhuang, L.; Lu, J. Accounts Chem. Res. 2012, 45, 473. doi: 10.1021/ar200201x

(178) Nonjola, P. T.; Mathe, M. K.; Modibedi, R. M. Int. J. Hydrog Energy 2013, 38, 5115. doi: 10.1016/j.ijhydene.2013.02.028

(179) Wu, Y.; Wu, C.; Varcoe, J. R.; Poynton, S. D.; Xu, T.; Fu, Y. J. Power Sources 2010, 195, 3069. doi: 10.1016/j. jpowsour.2009.11.118

(180) XU, T. W.; Wu, Y. H.; Luo, J. X. Membrane Science Technology 2011, 31, 192. [徐铜文, 吴永会, 罗婧艺. 膜科学 与技术, 2011, 31, 192.]

(181) Li, X.; Yu, Y.; Meng, Y. ACS Appl. Mater. Interfaces 2013, 5, 1414. doi: $10.1021 / \mathrm{am} 302844 \mathrm{x}$

(182) Zhou, T.; Zhang, J.; Qiao, J.; Liu, L.; Jiang, G.; Zhang, J.; Liu, Y. J. Power Sources 2013, 227, 291. doi: 10.1016/j. jpowsour.2012.11.041

(183) Zhou, T.; Zhang, J.; Fu, J.; Jiang, G.; Zhang, J.; Qiao, J. Synthetic Metals 2013, 167, 43. doi: 10.1016/j. synthmet.2013.02.008

(184) Qiao, J.; Fu, J.; Liu, L.; Liu, Y. ; Sheng, J. Int. J. Hydrog Energy 2012, 37, 4580. doi: 10.1016/j.ijhydene.2011.06.038

(185) Zhao, Y.; Yu, H.; Xing, D.; Lu, W.; Shao, Z.; Yi, B. J. Membr Sci. 2012, 421-422, 311.

(186) Guo, T. Y.; Zeng, Q. H.; Zhao, C. H.; Liu, Q. L.; Zhu, A. M.; Broadwell, I. J. Membr. Sci. 2011, 371, 268. doi: 10.1016/j. memsci.2011.01.043

(187) Cao, Y. C.; Scott, K.; Wang, X. Int. J. Hydrog. Energy 2012, 
$37,12689$.

(188) Maurya, S.; Shin, S. H.; Kim, M. K.; Yun, S. H.; Moon, S. H. J. Membr. Sci. 2013, 443, 28. doi: 10.1016/j. memsci.2013.04.035

(189) Zhao, Y.; Pan, J.; Yu, H.; Yang, D.; Li, J.; Zhuang, L. Int. J. Hydrog. Energy 2013, 38, 1983. doi: 10.1016/j. ijhydene.2012.11.055

(190) Zhang, F.; Zhang, H.; Qu, C.; Ren, J. J. Power Sources 2011, 196, 3099. doi: 10.1016/j.jpowsour.2010.11.102

(191) Switzer, E. E. O.; lson, T. S.; Datye, A. K.; Atanassov, P.; Hibbs, M. R.; Fujimoto, C.; Cornelius, C. J. Electrochim. Acta 2010, 55, 3404. doi: 10.1016/j.electacta.2009.12.073

(192) Qiao, J.; Zhang, J.; Zhang, J. J. Power Sources 2013, 237, 1. doi: 10.1016/j.jpowsour.2013.02.059

(193) Ranganathan, S.; Easton, E. B. Int. J. Hydrog. Energy 2010, 35, 1001. doi: 10.1016/j.ijhydene.2009.11.077

(194) Ranganathan, S.; Easton, E. B. Int. J. Hydrog. Energy 2010, 35,4871 .

(195) Miyazaki, K.; Abe, T.; Nishio, K.; Nakanishi, H.; Ogumi, Z. J. Power Sources 2010, 195, 6500. doi: 10.1016/j. jpowsour.2010.04.023

(196) Bhattacharyya, A.; Goswami, A. J. Phys. Chem. B 2009, 113, 12958. doi: 10.1021/jp9053605

(197) Zhuang, L.; Huang, A. B.; Lu, S. F.; Tao, J. T.; Xiao, C. B. A Kind of Preparation Method of Strongly Alkaline Polymer Electrolyte Membrane. CN Patent CN1560117, 2005-01-05. [庄 林, 黄爱宾, 卢善富, 陆君涛, 肖超渤. 一种强碱性聚合 物电解质膜的制备方法: 中国, CN1560117[P]. 2005-01-05.]

(198) Tomlin, D. W.; Fratini, A. V.; Hunsaker, M.; Adams, W. W. Polymer 2000, 41, 9003. doi: 10.1016/S0032-3861(00)00242-1

(199) Henkensmeier, D.; Cho, H. R.; Kim, H. J.; Kirchner, C. N.; Leppin, J.; Dyck, A. Polym. Degrad. Stabi. 2012, 97, 264. doi: 10.1016/j.polymdegradstab.2011.12.024

(200) Hu, J. W.; Zhang, H. M.; Zhai, Y. F.; Liu, G.; Yi, B. L. Int. J. Hydrog. Energy 2006, 31, 1855. doi: 10.1016/j. ijhydene.2006.05.001

(201) Leykin, A. Y.; Shkrebko, O. A.; Tarasevich, M. R. J. Membr. Sci. 2009, 328, 86. doi: 10.1016/j.memsci.2008.11.047

(202) Luo, H.; Vaivars, G.; Agboola, B.; Mu, S.; Mathe, M. Solid State Ionics 2012, 208, 52. doi: 10.1016/j.ssi.2011.11.029

(203) Xing, B.; Savadogo, Q. Electrochem. Commun. 2000, 2 , 697. doi: 10.1016/S1388-2481(00)00107-7

(204) Hou, H.; Sun, G.; He, R.; Wu, Z.; Sun, B. J. Power Sources
2008, 182, 95. doi: 10.1016/j.jpowsour.2008.04.010

(205) Hou, H.; Sun, G.; He, R.; Wu, Z.; Sun, B.; Jin, W.; Liu, H.; Xin, Q. Int. J. Hydrog. Energy 2008, 33, 7172.

(206) Hou, H.; Wang, S.; Jiang, Q.; Jin, W.; Jiang, L.; Sun, G. J. Power Sources 2011, 196, 3244. doi: 10.1016/j. jpowsour.2010.11.104

(207) An, L.; Zeng, L.; Zhao, T. S. Int. J. Hydrog. Energy 2013, 38, 10602. doi: 10.1016/j.ijhydene.2013.06.042

(208) Merle, G.; Hosseiny, S. S.; Wessling, M.; Nijmeijer, K. J. Membr. Sci. 2012, 409-410, 191.

(209) Yang, J. M.; Chiu, H. C. J. Membr. Sci. 2012, 419-420, 65.

(210) Nikol, V. M.; Zugi, D. L.; Maksi, A. D.; Saponji, D. P.; Kaninski, M. P. M. Int. J. Hydrog. Energy 2011, 36, 110041.

(211) Wu, Y. H. Preparation, Characterizations and Application of Organic-Inorganic Hybrid Anion-Exchange Membranes. Ph. D. Dissertation, University of Science and Technology of China, Hefei, 2009. [吴永会. 有机-无机杂化阴离子交换膜 的制备、表征和应用[D]. 合肥: 中国科技大学, 2009.]

(212) Wu, Y.; Wu, C.; Li, Y.; Xu, T.; Fu, Y. J. Membr. Sci. 2010, 350, 322. doi: 10.1016/j.memsci.2010.01.007

(213) Pan, W. H.; Lue, S. J.; Chang, C. M.; Liu, Y. L. J. Membr. Sci. 2011, 376, 225. doi: 10.1016/j.memsci.2011.04.026

(214) Zeng, L.; Zhao, T. S.; Li, Y. S. Int. J. Hydrog. Energy 2012, 37, 18425. doi: 10.1016/j.ijhydene.2012.09.089

(215) Ye, Y.; Cheng, M.; Xie, X.; Rick, J.; Huang, Y.; Chang, F.; Hwang, B. J. Power Sources 2013, 239, 424. doi: 10.1016/j. jpowsour.2013.03.021

(216) Fu, J.; Qiao, J. L.; Ma, J. X. Acta Phys. -Chim. Sin. 2010, 26, 2975. [傅 婧, 乔锦丽, 马建新. 物理化学学报, 2010, 26, 2975.] doi: 10.3866/PKU.WHXB20101014

(217) Liu, L. L.; Ding, L.; Xu, L.; Qiao, J. L.; Sheng, J. Acta Phys. -Chim. Sin. 2011, 27, 2665. [刘玲玲, 丁 蕾, 徐 莉, 乔锦丽, 盛 嘉. 物理化学学报, 2011, 27, 2665.] doi: 10.3866/PKU.WHXB20111106

(218) Wang, E. D.; Zhao, T. S.; Yang, W. W. Int. J. Hydrog. Energy 2010, 35, 2183. doi: 10.1016/j.ijhydene.2009.12.179

(219) Yang, C. C.; Chiu, S. J.; Lee, K. T.; Chien, W. C.; Lin, C. T.; Huang, C. A. J. Power Sources 2008, 184, 44.

(220) Yang, C. C.; Chiu, S. J.; Lin, C. T. J. Power Sources 2008, 177 40. doi: 10.1016/j.jpowsour.2007.11.010

(221) An, L.; Zhao, T. S.; Wu, Q. X.; Zeng, L. Int. J. Hydrog. Energy 2012, 37, 14536. doi: 10.1016/j.ijhydene.2012.06.105 